\title{
OCEANA
}

\section{Dirty Drilling: \\ Trump Administration Proposals Weaken Key Safety Protections and Radically Expand Offshore Drilling}

\author{
April 2019
}

Authors: Madeline Voitier and Diane Hoskins

DOI: $10.31230 /$ osf.io/fbgnc

\section{Executive Summary}

On April 20, 2010, the BP Deepwater Horizon oil rig exploded, tragically claiming the lives of 11 people and causing the worst oil spill in United States history. More than 200 million gallons of oil spilled over the 87 days it took to finally cap the well. The disaster wreaked havoc on the Gulf of Mexico coast and once again exposed the American public to the dangers of offshore oil and gas drilling.

An investigation into the disaster conducted by the National Commission on the BP Deepwater Horizon Oil Spill and Offshore Drilling (the National Commission) identified systemic failures in both industry management and government oversight as the underlying causes of the disaster. The National Commission recommended numerous reforms to government regulations and industry practices, including the formation of a new safety-focused regulatory body named the Bureau of Safety and Environmental Enforcement (BSEE) within the U.S. Department of the Interior (DOI).

Oceana reviewed government documents and reports, public reporting, and scientific literature and interviewed policy experts to determine the progress in safety since the BP disaster. Oceana found incremental improvements but also alarming unaddressed deficiencies. Reform efforts to date fall far short of what is needed to improve offshore drilling safety and many problems that undermine oversight of the industry remain.

Overarching issues with offshore oil and gas operations continue to compromise human safety and environmental protection. Moreover, the Trump administration is pushing to radically expand offshore drilling into nearly all U.S. waters while rolling back many of the few safety requirements currently in place. This report examines these issues and proposes policy changes to remedy them.

Key Findings:

\section{Regulatory Shortfalls Undermine Offshore Drilling Safety}

- BSEE's current inspection and enforcement actions do not result in comprehensive oversight of offshore drilling activities.

- BSEE regularly grants exemptions - "departures" or "alternate compliance" - from drilling safety requirements. One such exemption was issued before the BP Deepwater Horizon explosion and was 


\section{OCEANA}

later determined to have increased the risk of not being able to control the well. Loss of well control can result in a catastrophic blowout.

- BSEE's incorporation of industry-written standards into regulations does not ensure safety and allows the industry to govern itself without adequate independent oversight.

- Blowout preventers are the last line of defense against a catastrophic spill but are not reliable and have not been tested under conditions that replicate the extreme real-world environment to which they may be exposed.

- Grossly inadequate civil penalties fail to deter industry corner-cutting. Penalties are capped at $\$ 44,675$ per day per violation while operating costs for offshore drilling facilities can be approximately $\$ 1$ million per day.

\section{Offshore Industry's Safety Culture Has Not Sufficiently Improved}

Following the 2010 BP disaster, the National Commission called for "sweeping reforms" of the offshore industry and a "fundamental transformation of its safety culture." ${ }^{1}$ Despite public claims to the contrary, no meaningful evidence of such a transformation exists. Instead, industry appears to remain on a similar dangerous course to the one that resulted in BP Deepwater Horizon.

- Industry ignored the National Commission's recommendation to develop an independent organization focused solely on safety, and instead created an industry-affiliated organization rife with conflicts of interest.

- The offshore industry continues to struggle to improve its safety culture. On average, from 2007 to 2017, a fire or explosion erupted offshore every three days and hundreds of workers were injured annually. A recent series of surprise inspections of offshore facilities conducted by BSEE revealed numerous safety violations.

\section{Frequent Oil Spills Continue}

Large-scale spills tend to capture public attention, but many smaller spills are also polluting our waters. Spills can occur during every phase of development, including exploratory drilling, production and transportation. In U.S. federal waters, at least 6,500 oil spills occurred from 2007 to 2017.

- The oil spill reporting system is flawed-fines are based on spill amounts, which are generally estimated by the responsible party. Worse, it appears there is no requirement to update initial spill estimates. This likely incentivizes underreporting. Using satellite data, one study determined that spills are typically four times larger than reported.

- Oil spills cannot be cleaned up effectively, with methods that have largely remained unchanged since the late 1980s.

- Financial resources for oil spill clean-up are inadequate. An oil spill clean-up fund, used when a responsible party is unwilling or unable to pay, is capped at $\$ 1$ billion per spill, but clean-up costs alone amounted to over $\$ 14$ billion in the years directly following the BP disaster.

- Natural disasters and severe weather exacerbate the risk of oil spills. Hurricane-caused damage to oil and gas infrastructure is one of the leading causes of oil spills. A mudslide triggered by Hurricane Ivan sank the Taylor Energy oil platform located off the coast of Louisiana, burying numerous wells deep beneath sub-surface mud. According to court filings, these wells are still leaking roughly 10,000 to 30,000 gallons of oil per day. 


\section{TOCEANA}

- Despite federal requirements for companies to decommission their facilities and related infrastructure after oil production ends, when financially at-risk companies fail to do so, taxpayers may face the burden for those costs.

\section{Trump Administration Proposals Expand Drilling and Weaken Safety Measures}

In a complete reversal of U.S. offshore energy policy, the Trump administration is proposing to expand offshore drilling to nearly all U.S. waters, while simultaneously dismantling many of the few offshore safety regulations put in place following the BP Deepwater Horizon disaster. These efforts include weakening the Well Control Rule that was enacted in response to the BP catastrophe by removing requirements for BSEEapproved independent verification organizations; weakening real-time monitoring of offshore operations by on-shore monitors; and watering down testing requirements for critical safety devices like blowout preventers.

BSEE estimates the proposed safety rollbacks will save the offshore oil and gas industry about \$824 million over 10 years. Focusing on industry cost-savings, however, disregards the safety and environmental benefits the rule was intended to provide in the first place. Moreover, BP's estimated losses due to the Deepwater Horizon disaster amounted to over $\$ 60$ billion, or more than 70 times the estimated 10-year savings from decreasing safety standards. This focus on short-term cost savings to industry is shortsighted and does not ensure offshore drilling safety.

\section{Recommendations}

Overarching issues with the regulation of offshore oil and gas operations continue to compromise safety and environmental protection. Instead of weakening key safety measures already in place, we should be implementing safety reforms to prevent another environmental catastrophe. Oceana has the following recommendations:

- President Trump should direct his administration to halt all efforts to expand offshore drilling activities to new areas and abandon attempts to weaken safety regulations.

- BSEE should seek transformative changes to industry's safety culture through greater inspections and enforcement and by reducing reliance on industry-written standards.

- Congress must substantially increase financial penalties for safety violations to disincentivize dangerous, non-compliant behavior and ensure that risk-taking is no longer profitable.

- Congress must require accurate oil spill reporting, establish penalties for under-reporting, increase federal resources and research new clean-up technologies.

- $\quad$ The United States must shift to renewable energy sources like offshore wind.

\section{Introduction}

The BP Deepwater Horizon disaster was an avoidable tragedy that killed 11 people and spilled more than 200 million gallons of oil into the Gulf of Mexico. This catastrophe revealed critical inadequacies in safety, regulation and oversight in the offshore oil drilling industry. Almost 10 years later, those insufficiencies have yet to be adequately addressed-making another disaster just a matter of time. Poor oversight and regulation of the industry also result in ongoing risks to the environment and human safety. The federal 


\section{OCEANA}

government has failed to adopt or implement comprehensive safety measures necessary to rein in this risky industry. To make matters worse, President Trump is rolling back key offshore safety standards put in place after the BP Deepwater Horizon disaster, while simultaneously pushing to expand offshore drilling operations to nearly all U.S. waters.

The offshore oil and gas industry has a history of corner-cutting and unsafe, dangerous drilling practices. This has been well-documented in the aftermath of previous major U.S. oil spill disasters, such as the 1969 Santa Barbra oil spill ${ }^{2,3}$ and the 2010 BP Deepwater Horizon disaster, ${ }^{4}$ and continues to be an issue. ${ }^{5,6,7}$ Despite its poor track record, the industry has consistently fought federal regulation, asserting that industry expertise, not regulation, achieves safety. ${ }^{8,9}$ While industry expertise can help inform safety regulations, allowing oil and gas companies to operate without independent oversight has led to disastrous results.

The BP Deepwater Horizon oil rig blowout caused one of the worst manmade environmental catastrophes in history. ${ }^{10}$ This disaster killed 11 rig workers, spilled over 200 million gallons of oil, ${ }^{11}$ fouled at least 1,300 miles of Gulf shoreline, ${ }^{12}$ endangered public health, ${ }^{13}$ and killed tens of thousands birds, sea turtles, dolphins and fish. ${ }^{14}$ In response, President Obama created the National Commission to investigate the causes of the disaster, improve the United States' oil spill response ability and recommend reforms to make offshore energy production safer. ${ }^{15}$

After extensive investigation, the National Commission determined that the root causes of the spill were systemic failures of both industry management and the government's inadequate oversight of the offshore industry. ${ }^{16}$ To address these issues, the National Commission recommended numerous measures to increase safety in the industry, which prompted the government to institute regulatory reform efforts. ${ }^{17,18}$ However, these reforms fall short of what is needed to improve offshore drilling safety. ${ }^{19,20,21}$

This report examines three overarching issues involved in offshore operations and proposes policy changes to remedy them. First, systemic problems in the regulation of offshore drilling severely undermine the effectiveness of safety measures. Second, oil spills-large and small-continue to pollute the environment under a system that fosters spills rather than deterring them. Third, President Trump is dismantling key safety protections put in place after the BP Deepwater Horizon disaster, while simultaneously proposing to expand offshore drilling to nearly all U.S. waters.

\section{Regulatory Shortcomings Undermine Offshore Drilling Safety}

Fundamental issues in the regulation of the offshore oil and gas industry have not been sufficiently addressed since the BP Deepwater Horizon disaster. Lack of adequate government oversight paired with an industry resistant to change put workers and the oceans at unnecessary risk.

As a result of these shortcomings, offshore drilling remains a dangerous and dirty practice despite BSEE's efforts.

Government Oversight of Offshore Drilling Industry Lacking 


\section{OCEANA}

BSEE is supposed to promote offshore safety, protect the environment and conserve offshore resources through regulatory oversight and enforcement. ${ }^{22}$ Unfortunately, BSEE lacks the resources and policies necessary to carry out its responsibilities effectively. ${ }^{23}$

\section{BSEE Inspections and Enforcement Ineffective}

BSEE's current inspection and enforcement actions do not result in comprehensive oversight of offshore drilling activities. Considering the complexity of offshore drilling operations, BSEE inspectors are stretched quite thin, especially in certain parts of the Gulf of Mexico. ${ }^{24,25}$ As of 2018, BSEE employed roughly 120 inspectors nationwide to conduct more than 20,000 inspections annually. ${ }^{26} \mathrm{BSEE}$ is only legally required to conduct announced inspections of each offshore facility at least once a year and to conduct unannounced inspections on a "periodic" basis. ${ }^{27}$ Additionally, BSEE has reportedly had trouble hiring employees to bolster its workforce, because it struggles to compete with the lucrative salaries offered by the oil and gas industry. ${ }^{28}$

In 2016, the Government Accountability Office (GAO) found severe inadequacies in BSEE's ability to carry out effective investigations, ensure environmental compliance and conduct enforcement. ${ }^{29} \mathrm{GAO}$ noted that BSEE lacks the capabilities to properly utilize enforcement tools (i.e., warnings and fines) and continues to use insufficient pre-Deepwater Horizon incident policies and procedures. ${ }^{30,31}$ In 2017, GAO reported BSEE had made limited progress in addressing these deficiencies ${ }^{32}$ and added offshore oil and gas oversight to its "high-risk series"-a program aimed at identifying government operations with vulnerabilities to fraud, waste, abuse and mismanagement. ${ }^{33}$ To remedy deficiencies in their oversight abilities, GAO called for BSEE to complete policies establishing responsibilities for investigations, environmental compliance and enforcement programs, and to update and develop guidance for those programs. ${ }^{34}$ As of March 2019, BSEE had yet to make progress on many of those recommendations. ${ }^{35}$

BSEE has taken nominal steps to remedy shortcomings described by GAO by commissioning a study to evaluate and improve its inspection capabilities ${ }^{36}$ and launching a risk-based inspection program in March 2018. ${ }^{37}$ Unfortunately, BSEE undermined these improvement efforts when, under the auspices of the President's pro-drilling agenda, it proposed removing requirements for BSEE Approved Verification Organizations (BAVOs) to certify and inspect blowout preventer systems. ${ }^{38}$ BSEE previously suggested that BAVOs would add an extra layer of review and verification of these critically important systems ${ }^{39}$ by providing independent engineering oversight of blowout preventers. ${ }^{40}$ Without BAVOs, the industry is allowed to self-govern.

Insufficient inspection rates, lack of independent reviewers and weak enforcement undermine regulatory compliance by leaving potential violators unencumbered by proper regulatory oversight. To fulfill its mandate, BSEE should not be reducing oversight of offshore drilling. Rather, it should increase inspections (both announced and unannounced) and develop procedures to reliably enforce safety regulations.

\section{BSEE Grants Industry Exemptions from Drilling Regulations}

Currently, provisions in BSEE regulations allow the agency to grant exemptions to crucial safety requirements in the form of departures or alternate procedures or equipment (alternative compliance). ${ }^{41}$ To be granted a departure or alternative compliance, the operator must apply in writing to the district manager or regional supervisor. ${ }^{42}$ In order to use alternative compliance measures, the operator must 


\section{OCEANA}

"provide a level of safety and environmental protection that equals or surpasses current BSEE requirements." ${ }^{43}$ Presently, it appears that no such criteria exist for when a departure can or cannot be granted; applicants must merely explain their request. ${ }^{44}$

While exemptions can provide operators some level of flexibility to respond to unexpected circumstances, they may also undermine regulatory requirements. The BP Deepwater Horizon disaster provides one such example. The Mineral Management Service (MMS), which was the regulatory authority at the time and preceded BSEE, granted BP a departure on April 16, 2010.45 Specifically, regulations required that during temporary well abandonment, a cement plug must be set no more than 1,000 feet below the seafloor or wellhead. ${ }^{46}$ Regardless, MMS approved BP's request to set the cement plug 3,300 feet below the seafloor. ${ }^{47}$ This departure request was approved in less than 90 minutes. ${ }^{48}$ Four days later, the rig exploded. The Deepwater Horizon Joint Investigation Team later determined that setting the cement plug at that depth created a "risky situation" and further increased the well control risks. ${ }^{49}$

Recently, Politico reported that BSEE granted 1,700 exemptions to safety requirements put in place after the BP Deepwater Horizon disaster. ${ }^{50}$ Politico reported that BSEE allowed numerous provisions of the Well Control Rule to be sidestepped by operators, including testing requirements for blowout preventer systems - the device that failed to prevent the BP Deepwater Horizon blowout. ${ }^{51}$ According to Politico, the BSEE spokesperson said that these departures and alternative compliance are permitted under the Well Control Rule, but that BSEE "does not track requests and is not required to make them public since they may include company's trade secrets." ${ }^{2}$ Specifically, the BSEE spokesperson stated that "[i]n approving the permits, the BSEE engineers verify that any proposed alternate procedures or equipment provide a level of safety and environmental protection that equals or exceeds current BSEE regulations." 53 The Politico report raises concerns that key provisions of the rule, which went through full public review with input from industry, may not be going into effect after all.

The frequency of departures and alternative compliance, and details about the circumstances under which they are granted - including the rigor, if any, of the oversight - are not readily available to the public. The process through which safety regulations can be easily rescinded is not transparent and creates opportunities for side-stepping rules that are vital to protecting human and environmental health as well as safety. This process should be more transparent and accountable.

\section{BSEE Incorporates Industry-Written Safety Standards into Regulations}

Regulators of a complex and highly technical industry like offshore drilling must walk a fine line. On one hand, it is important for regulators to work with operators to understand practical operating conditions, but it is also critical for the role of the regulator not to be compromised by industry influence. To fill this need for truly independent oversight, BSEE was created as a separate agency solely focused on offshore safety and environmental protection. ${ }^{54}$

BSEE publishes the safety requirements for offshore oil and gas operations. ${ }^{55}$ Federal regulators, however, have a longstanding history of directly incorporating standards written by industry-backed organizations such as the American Petroleum Institute (API). ${ }^{56,57,58,59,60,61} \mathrm{API}$ is an industry trade association that produces standards that cover many facets of industry operations. ${ }^{62}$ The development of these standards does not involve the general public ${ }^{63}$ and often results in standards that are not always enforceable by regulators because they can use words like "should" rather than "shall." ${ }^{4}$ According to the National 


\section{OCEANA}

Commission report, "because they would make oil and gas industry operations potentially more costly, API regularly resists agency rulemaking that government regulators believe would make [oil and gas] operations safer, and API favors rulemaking that promotes industry autonomy from government oversight." ${ }^{\prime 5}$ In the end, BSEE relies heavily on industry-written safety standards to regulate offshore drilling and does not provide adequate oversight or enforcement.

The government's over-reliance on industry assurances as to what constitutes safe drilling practices was highlighted in the BP Deepwater Horizon disaster investigation. ${ }^{66}$ The National Commission cautioned against the incorporation of industry standards, because it found that "API's ability to serve as a reliable standard-setter for drilling safety is compromised by its role as the industry's principal lobbyist and public policy advocate." 67 The National Commission reported that API safety standards "have increasingly failed to reflect 'best industry practices' and have instead expressed the 'lowest common denominator' - in other words, a standard that almost all operators could readily achieve." ${ }^{\prime 8}$ The National Commission's report maintained that regulators' reliance on API safety standards to develop their own federal safety regulations, undermines the entire federal regulatory system. ${ }^{69}$

These official industry safety standards are privately owned by API and are not reasonably available to the public, even after they become legally binding and incorporated into federal regulation. ${ }^{70,71}$ Incorporated API standards may be available for "free" online in read-only form, meaning the document cannot be downloaded for later review. ${ }^{72}$ To examine the standard, one must register with API and accept its terms of use, and API may suspend or discontinue this access without cause or notice. ${ }^{73}$

These viewing restrictions can be extremely limiting when analyzing lengthy technical standards that can be over a hundred pages. ${ }^{74}$ Anyone who wants hard copies or printable versions of the standards must purchase them from API, and individual standards typically cost around $\$ 100$ or more. ${ }^{75,76}$ BSEE has hard copies of the incorporated standards, but you must visit a BSEE office and read them there; no copies of the documents are allowed off the premises. ${ }^{77}$ These standards are extremely long and technical and may require multiple visits to fully review. All these inconveniences act as barriers to public accountability.

Despite warnings from the National Commission, incorporation of API safety standards continues to be the norm. ${ }^{78,79}$ The National Commission has called these industry-owned standards the "lowest common denominator" in safety. By incorporating industry-written standards, BSEE relinquishes its independence, blurring the line between regulator and regulated, which ultimately compromises its ability to ensure public safety.

\section{Blowout Preventers Not Reliable Due to Critical Shortcomings}

Deepwater drilling is inherently risky due to extreme pressures and geologic uncertainties present in oil and gas formations thousands of feet below the seafloor. ${ }^{80}$ The Macondo well, which the BP Deepwater Horizon tapped, was located a mile beneath the ocean floor ${ }^{81}$ Extraction from these reservoirs requires a delicate balance between the pressure in the oil and gas reservoir and the counter-pressure from inside the well. Higher pressure in the reservoir can cause uncontrolled flow into the well, while higher pressure inside the well may fracture the rock formation. Moreover, the deeper the well, the higher the pressure, making deeper reserves more complicated to extract. ${ }^{82}$

If these pressures are not balanced exactly, oil and gas can flow into the well-called a "kick"-and if this is not remedied quickly, the fluids can rush up out of the well causing a "blowout." 83 The various tools used in 


\section{OCEANA}

deep water drilling-such as drilling mud, cement and well casing-are meant to allow the drilling team to control the well pressure. When these tactics fail, a blowout preventer should be triggered, and this should seal the well. ${ }^{84}$

Blowout preventers are the last line of defense against a well blowout, also known as loss of well control. ${ }^{85}$ Unfortunately, these devices do not always prevent blowouts. ${ }^{86,87,88}$ Blowout preventers contain multiple components designed to do the same thing in order to create redundancies in the event any single component fails. The various components of a blowout preventer are known as a stack. ${ }^{89}$ Within blowout preventer stacks, there are multiple sets of rams, which are designed to seal the well and trap rising oil and gas (see Figure 1)..$^{90}$ In the case of Deepwater Horizon, the blind shear ram-a set of rams inside the blowout preventer stack used to cut through and seal the drill pipe, preventing oil and gas flow to the surface-failed to properly cut (or shear) and seal the pipe, rendering the blowout preventer powerless to stop the blowout. ${ }^{91}$

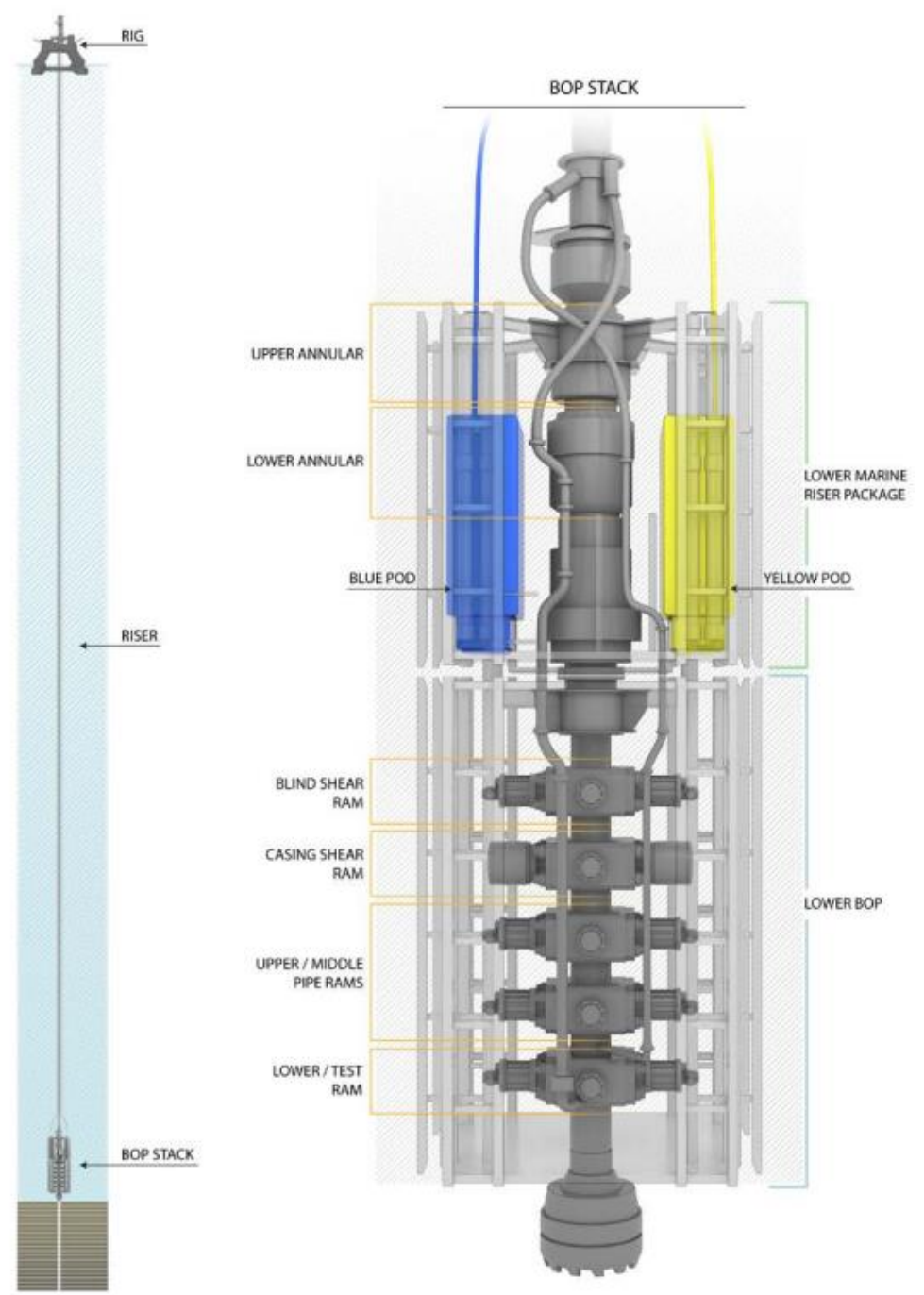

Figure 1: BP Deepwater Horizon blowout preventer. Credit: U.S. Chemical Safety and Hazard Investigation Board, Investigation Report Volume 2, Explosions and Fire at the Macondo Well (June 2014). 


\section{OCEANA}

An investigation commissioned by DOI determined that the drill pipe buckled within the blowout preventer. When the pipe buckled under extreme pressure, it moved outside the reach of the blind shear rams, which were supposed to cut and seal the pipe. ${ }^{92}$ Due to this malfunction, pressurized oil gushed unrestricted into the surrounding environment for 87 days until the well was eventually capped. ${ }^{93}$ Investigators attributed the pipe buckling to the forces generated from the blowout (i.e., from oil and gas surging upwards through the drill pipe). ${ }^{94,95}$ Simply put, the very event that blowout preventers are supposed to shield against-a blowout-was responsible for the failure of Deepwater Horizon's blowout preventer.

BP Deepwater Horizon and the resulting investigations suggested that blowout preventers at the time may have been flawed and possibly unable to withstand the forces generated by high-pressure blowouts. ${ }^{96,97}$ Specifically, the Deepwater Horizon Joint Investigation Team recommended that the government research the effects of a flowing well on the ability of a blowout preventer to shear pipe, and also research a blind shear ram design that incorporates an improved pipe-centering shear ram. ${ }^{98}$ As a result of the investigation's findings, BSEE issued the Blowout Preventer Systems and Well Control Rule, known commonly as the Well Control Rule, in 2016. The Well Control Rule requires blowout preventers to be equipped with two shear rams and another device to keep the drill pipe centered during shearing operations. ${ }^{99}$ BSEE recently proposed removal of the pipe-centering requirements. ${ }^{100}$ Still concerning, however, is that blowout preventers are not tested under extreme flowing or worst-case scenario conditions. ${ }^{101}$ The Well Control Rule does not require a blowout preventer's individual rams to be tested and merely requires that the system be capable of sealing the well under "anticipated flowing conditions," which likely do not amount to the extreme flowing conditions that could arise. ${ }^{102}$ Additionally, this overall system approach may not be enough to prevent a blowout, since the Deepwater Horizon's blowout preventer had several layers of redundancy that all failed during the disaster. ${ }^{103}$

One panelist during a 2012 BSEE blowout preventer forum argued "if [blowout preventers] are going to be expected to work under conditions where all hell is breaking loose, they have to be tested in conditions that simulate all hell breaking loose." ${ }^{104}$ A 2015 study found that this common-sense approach to testing was not happening. ${ }^{105}$ The study used the conditions present during the Macondo well blowout as a basis for the worst-case physical test conditions-referred to as "Macondo conditions." ${ }^{\text {"106 }}$ Overall, the study found shear rams were not designed nor being tested under these flowing well conditions. ${ }^{107}$

According to this study, surveyed industry personnel asserted that shear rams are not designed for flowing well conditions because the chance of shear rams encountering flowing conditions is low; other components of the blowout preventer are expected to stop the high velocity flow of oil and gas by the time the shear rams are activated. ${ }^{108}$ Additionally, the study highlighted that replicating high flows and pressures during the Macondo incident may be complicated and expensive, and raises safety concerns. ${ }^{109}$ If any of these components fail, however, shear rams can still be exposed to flowing conditions. ${ }^{110}$ In fact, Deepwater Horizon's blowout preventer shear rams were exposed to high velocity fluid when the other components of the blowout preventer failed to stop the flow of oil and gas-resulting in the blowout. ${ }^{111}$ This challenges the decision to use a blowout preventer to begin with, since it cannot be tested under the extreme, real-world conditions it could ultimately face.

The Bureau of Transportation Statistics (BTS) released an annual report on blowout prevention system safety, as required by the Well Control Rule. ${ }^{112}$ The report summarized equipment failures on drilling rigs in the Gulf of Mexico. ${ }^{113}$ In 2017, 18 out of 25 operators associated with rig operations in the Gulf reported 1,129 equipment component failure events. ${ }^{114}$ These 18 operators who reported equipment failures 


\section{OCEANA}

represent about 90 percent of new wells drilled in the Gulf-a region that accounts for 98 percent of annual oil production on the OCS. ${ }^{115}$ The report also showed that in 2017, most equipment failures (57.7 percent) were detected during testing, which was more than during inspections, periodic maintenance or casual observation combined. ${ }^{116}$ In 2017, there was one reported well control incident involving leaking drilling fluids that luckily did not lead to a loss of well control. ${ }^{117}$ Importantly, there were no losses of well control in $2017,{ }^{118}$ a positive trend which could be jeopardized by regulatory rollbacks.

Nevertheless, the oil and gas industry continues to fight against frequent equipment testing requirements. ${ }^{119}$ And industry appears to be getting what it wants. BSEE has proposed to drastically reduce blowout preventer system testing requirements in the Well Control Rule, saying reduced testing will decrease wear and tear on the blowout preventer equipment. ${ }^{120}$ The claim that less testing results in more safety ignores the fact that more than half of the equipment failures identified in the 2017 safety report were found during testing. ${ }^{121}$

On top of inadequate testing requirements, blowout preventers are also subject to operator error. Mechanisms can be unintentionally miswired or poorly maintained, thereby rendering them useless during a blowout-as seen in the case of Deepwater Horizon, where investigators identified multiple instances of miswiring in the rig's blowout preventer. ${ }^{122}$

Blowout preventers may not be reliable and suffer from critical shortcomings that must be remedied. They should be tested under extreme conditions and tested often. Unfortunately, since no alternative blowout prevention strategy exists, blowout preventers remain the last line of defense with no real assurance that they will, in fact, prevent a blowout.

\section{Grossly Inadequate Civil Penalties Fail to Deter Industry Corner-Cutting}

Current civil penalties, or fines, are inadequate to deter risk-taking and fail to deter industry corner-cutting because of a significant imbalance between fines and offshore oil and gas operating costs. For example, operating costs for offshore drilling facilities can be approximately $\$ 1$ million per day (e.g., BP Deepwater Horizon rig), ${ }^{123}$ while civil penalties for violations are capped at $\$ 44,675$ per day per violation. ${ }^{124}$ Worse yet, many violations do not even trigger fines. ${ }^{125} \mathrm{~A}$ fine may be required if the violation threatens or actually causes "serious, irreparable or immediate harm or damage to life, property or the environment" or if the violation is not corrected within a timeframe specified by BSEE. ${ }^{126,127}$ This high threshold to prompt penalties, coupled with relatively low-cost fines, results in less safety because companies may simply pay the fines instead of making changes that could require a delay in operations and impact profits.

In 2016, BSEE issued 2,643 incidents of non-compliance, only 38 of which were referred to the civil penalty process. ${ }^{128}$ From the 28 cases resolved that year, the industry paid nearly $\$ 2.5$ million ${ }^{129}$-meaning the civil penalties collected over one year, for the entire offshore oil and gas industry, amounted to less than three days of operating costs for the Deepwater Horizon rig. ${ }^{130}$ This shows there is a financial incentive to ignore regulatory compliance and cut corners to protect profits. The safety of rig workers and the environment will continue to be threatened until this disparity is remedied.

While civil penalties were marginally increased for inflation in 2019 to $\$ 44,675$ a day for each violation, ${ }^{131}$ the penalties are still not nearly enough to deter regulatory corner-cutting, since operating costs remain much higher and industry profits number in the billions per year. ${ }^{132}$ Safety violations are a threat to workers and the environment. Congress should increase civil penalties substantially, so they provide an incentive to 


\section{OCEANA}

prevent non-compliant behavior and ensure that risk-taking is no longer profitable in the short term.

\section{Potential for Operator Error Remains Safety Issue}

Proper installation of the mandated safety technology can still be undermined by operator error-a contributing cause of the BP disaster. Several key warning signs were missed by the Deepwater Horizon crew leading up to the blowout-including a misread of a pressure test and an unnoticed "kick" (the precursor to a blowout) that was building in the well below. By the time the crew realized what was happening, it was already too late, and the blowout was underway. ${ }^{133}$

During emergency conditions, people and equipment do not always perform as expected. ${ }^{134}$ With BSEE's limited oversight capacity and the industry's substantial economic incentives to prioritize production over safety, it is unsurprising that human error in installation and operation of these complex technologies continues to be an issue. ${ }^{135,136,137}$ Improved training for operators, such as simulated-based training, ${ }^{138}$ may help reduce operator error, but effective oversight of this industry is still needed to ensure mistakes are avoided. ${ }^{139}$

\section{Offshore Industry's Safety Culture Has Not Improved Sufficiently Since BP Deepwater Horizon}

Following the 2010 disaster, the National Commission called for "sweeping reforms" by the oil and gas industry that would amount to a "fundamental transformation of its safety culture." ${ }^{140}$ Some companies have made commitments to improve safety, and many diligent, hard-working individuals in the industry focus on safety every day. However, the industry as a whole has not adequately embraced efforts to strengthen independent oversight and improve its safety culture. ${ }^{141}$ Instead, industry continues to push for regulatory rollbacks while claiming publicly it holds safety as a top priority. ${ }^{142}$

\section{Safety and Environmental Management Systems Requirements}

In an effort to drive this fundamental transformation of the industry's safety culture, federal regulators required Safety and Environmental Management Systems (SEMS), a previously voluntary measure, to be mandatory for all offshore operators. ${ }^{143}$ SEMS was made mandatory after the BP Deepwater Horizon disaster, since previous attempts to do so were impeded by years of industry-fueled delay. ${ }^{144}$ The goal of SEMS is to shift the offshore industry from a compliance mentality, under prescriptive regulations, to a more performance-based overarching safety management approach. ${ }^{145}$

SEMS requires offshore operators to proactively identify, analyze, and manage safety, environmental hazards, and impacts at all stages of offshore resource development. ${ }^{146}$ Additionally, SEMS requires operators to develop and implement a stop work authority "that creates procedures and authorizes any and all offshore industry personnel who witness an imminent risk or dangerous activity to stop work." 147 Operators must also undergo SEMS audits of their programs by an independent accredited audit service provider. ${ }^{148}$ These accredited audit service providers are verified by the Center for Offshore Safety, which is discussed in more detail further below. ${ }^{149}$

While requiring SEMS sends an important signal to the industry that the regulator has expectations about improving safety behavior, it is hard to quickly force a change in culture. Possibly, for some bad actors, the 


\section{OCEANA}

change will never come. But as the National Commission pointed out, "the Deepwater Horizon disaster made unambiguously clear, [that] the entire industry's reputation, and perhaps its viability, ultimately turn on its lowest-performing members." ${ }^{150}$

\section{Industry Ignored Recommendations from National Commission}

The National Commission recommended the creation of an industry safety institute to supplement government oversight of offshore industry operations. ${ }^{151}$ The National Commission stressed that this entity must be solely focused on safety and maintain independence from any appearance that its credibility could be compromised by other private interests and agendas. ${ }^{152}$ In response to the National Commission's report, API stated that it had "begun the process of creating an industry safety program for deepwater operations" in order to "help further drive a culture of excellence throughout the offshore industry." 153 The National Commission was clear about the need for independence, writing: "[a]s a consensus-based organization, $[\mathrm{API}]$ is culturally ill-suited to drive a safety revolution in the industry. For this reason, it is essential that the safety enterprise operate apart from the API." ${ }^{\text {154 }}$

Subsequently, industry created the Center for Offshore Safety, a supposedly "independent" safety organization. However, contrary to the National Commission's clear mandate, this organization is directly affiliated with API. ${ }^{155}$ Moreover, membership is voluntary, and many offshore operators opt out of participating. ${ }^{156}$

A 2016 study conducted by the National Academies of Sciences, Engineering, and Medicine suggested that low membership levels may be due to membership fees and the requirement that members undergo safety management system audits. ${ }^{157,158}$ The study raised questions about the Center for Offshore Safety's objectivity and credibility due to its affiliation with API and urged the offshore industry to implement the National Commission's recommendation for an independent safety organization without ties to private interests. ${ }^{159}$ Truly independent industry oversight is vital to supplement federal regulatory measures.

\section{Offshore Drilling Industry Continues to Struggle with Safety}

The offshore industry continues to struggle to improve its safety culture. ${ }^{160}$ From 2007 to 2017 there were an average of 120 fires and explosions on the OCS per year-meaning on average, a fire or explosion erupted offshore every three days. ${ }^{161,162}$ Hundreds of workers were injured every year during that period. ${ }^{163}$ A recent series of surprise inspections of offshore facilities conducted by BSEE revealed numerous safety violations. ${ }^{164,165,166}$

According to recent government data, many offshore operators continue to be cited for safety violations. ${ }^{167}$ In 2018 alone, BSEE issued a total of 699 incidents of non-compliance shut-ins in the Gulf of Mexico. ${ }^{168}$ Shut-ins are considered the most severe enforcement action, and are ordered when BSEE detects an immediate threat to safety or the environment. ${ }^{169,170}$ When issued, they require the operator to remedy the violation before the activity can continue. ${ }^{171}$ Considering the infrequency of inspections and that operators are often given advance notice about inspections, the violations indicate ongoing safety issues. Additionally, in recent years, the Office of Inspector General discovered that some operators falsified blowout preventer test results in order to continue operating. ${ }^{172,173}$

At the time of the Deepwater Horizon disaster that killed 11 rig workers, the U.S. offshore oil industry had the highest reported rates of fatalities among its international peers, but the lowest reported injuries, 


\section{OCEANA}

according to the National Commission. ${ }^{174}$ The National Commission also reported that from 2004 to 2009 , U.S. offshore industry fatalities were more than four times higher in the United States than in European waters. ${ }^{175}$ The National Commission speculated that this imbalance suggested a significant under-reporting of injuries in the U.S. oil and gas industry. ${ }^{176}$

According to the Center for Disease Control and Prevention, the oil and gas industry's fatality rate (both onshore and offshore) in the United States was an average of seven times higher than among other U.S. workers in general between 2003 and $2013 .{ }^{177}$ According to the most recently published BSEE data since the BP Deepwater Horizon disaster, between 2011 and 2017, offshore operators on the OCS reported 1,568 injuries. ${ }^{178}$ Overall, these numbers demonstrate the inherent danger in offshore oil and gas activities.

\section{System that Fosters Spills Threatens Coastal Ecosystems}

Thousands of oil and chemical spills occur in U.S. waters every year. ${ }^{179,180}$ This includes large-scale disasters - such as the BP Deepwater Horizon, which took human lives, devastated marine ecosystems and inflicted tens of billions of dollars in economic damage ${ }^{181}$-as well as many smaller spills. Despite still causing damaging environmental impacts, smaller spills receive less media attention, regulatory oversight and clean-up resources. ${ }^{182}$

Oil spills can be caused by equipment failures, human error or natural disasters, including mudslides and hurricanes. ${ }^{183,184,185,186}$ In offshore oil and gas activities, spills can occur during every phase of development, including exploration, production and transportation. ${ }^{187}$ In U.S. federal waters, BSEE reported at least 6,500 oil spills from 2007 to $2017 . .^{188}$

Since 1964, there have been 17 large spills-which are defined as more than 1,000 barrels, or over 42,000 gallons. ${ }^{189}$ Chronic spills can occur over multiple years and are often larger than reported when compared to satellite images of the oil slicks. ${ }^{190}$

The damage from oil spills is further exacerbated by the inadequate framework currently in place for oil spill reporting and clean-up. The oil spill reporting system is unreliable; oil spill clean-up methods are ineffective and essentially have not advanced in decades; and financial resources available for clean-up are limited.

\section{Flawed Oil Spill Reporting System}

The discharge of oil or hazardous substances into U.S. waters is prohibited. ${ }^{191}$ By law, offshore operators must report oil spills to the U.S. Coast Guard's National Response Center (NRC). ${ }^{192}$ NRC then reports and coordinates oil spill response among various agencies. ${ }^{193}$ In determining the extent of the spill, the Coast Guard largely relies on unverified spill estimates put forward by responsible parties or third-party observers. ${ }^{194,} 195 \mathrm{It}$ appears that no requirement exists for initial spill estimates to be updated by the responsible party once additional information becomes available. ${ }^{196}$

Under the Clean Water Act, fines levied against a responsible party are calculated by the number of barrels of oil spilled. ${ }^{197}$ The statute sets maximum fine amounts, capping penalties at $\$ 1,895$ per barrel, generally, but this rate can increase up to $\$ 5,683$ per barrel if a party is found to be grossly negligent. ${ }^{198}$ This process may incentivize underestimating spills because there appears to be no requirement that a spill estimate be updated later, ${ }^{199}$ only that a spill be reported initially. ${ }^{200}$ 


\section{OCEANA}

Spills are typically far larger than reported. One study determined that oil spill estimates are, on average, over four times larger than the estimates reported to the NRC. ${ }^{201}$ Rampant underreporting of oil spill size makes clean-up efforts more difficult. More rigorous accountability relying on independent verification of spill estimates is needed to ensure an adequate clean-up response is implemented.

\section{Oil Spill Clean-Up Methods Limited}

Technologies for cleaning up oil spills have largely remained unchanged since the Exxon Valdez spill in the late 1980s, and are generally ineffective. ${ }^{202,203}$ Current clean-up methods include deploying booms to contain spilled oil, skimmers to remove the oil from the water, burning off the oil, and using chemical dispersants to break up the oil into smaller droplets. ${ }^{204}$ After the clean-up activities following the BP Deepwater Horizon disaster, the volume of oil remaining in the environment was estimated to be up to 60 million gallons, which is more than five times the size of the Exxon Valdez spill. ${ }^{205,206,207}$

Some have likened these methods to an exercise in spill "response theater" meant to convey the illusion of clean-up to the public without delivering on the promise. ${ }^{208}$ E\&E News reported that the Coast Guard Admiral in charge of the BP Deepwater Horizon clean-up recalled that during the spill, seas over four feet rendered the Coast Guard's ability to remove the oil "virtually impossible."209

Considering these limitations, President Trump's push to expand offshore drilling into places like the Arctic are especially troubling. There is no proven way to clean up spilled oil in the icy and remote conditions of the Arctic, where four-foot seas, like those that hampered the clean-up in the Gulf of Mexico, are considered a good day. ${ }^{210}$ Expanding offshore drilling when oil spill recovery methods are so inadequate is ill-advised and reckless.

\section{Financial Resources for Oil Spill Clean-Up Inadequate}

The Oil Pollution Act of 1990 (OPA) established a liability framework for parties who discharge oil in U.S. waters, including "navigable waters, adjoining shorelines or the exclusive economic zone." ${ }^{11}$ Under OPA, a responsible party is liable for all removal costs, plus a variety of damages resulting from the spill. ${ }^{212} \mathrm{~A}$ responsible party's liability for damages in particular, however, is limited under OPA. ${ }^{213}$ For example, damages (not including removal costs) resulting from a spill from an offshore facility are limited to $\$ 75$ million. $^{214}$ This damages cap, however, does not apply if the spill is determined to be the result of gross negligence, willful misconduct or violation of federal safety, construction or operation regulations by the responsible party. ${ }^{215} \mathrm{BP}$ 's liability for damages was not subject to these limitations because the spill was found to be the result of gross negligence and willful misconduct. ${ }^{216}$ To date, the BP Deepwater Horizon spill has reportedly cost BP over $\$ 60$ billion in clean-up costs and legal fees. ${ }^{217}$

Unlike BP, not every responsible party has the financial means ready to pay for clean-up costs from a catastrophic oil spill. To ensure that financial resources are available for rapid oil spill response efforts in the event the responsible party is unable or unwilling to pay, Congress established the Oil Spill Liability Trust Fund, funded through OPA. ${ }^{218,219}$ Currently, the fund contains approximately $\$ 6.7$ billion. ${ }^{220}$ However, the main source of revenue, a per-barrel excise tax on petroleum produced in or imported to the United States, ${ }^{221}$ expired at the end of 2018 and has yet to be renewed. ${ }^{222,}{ }^{223}$ Moreover, this fund has a $\$ 1$ billion cap per oil spill, ${ }^{224}$ which pales in comparison to the immediate and lasting economic and environmental damages a major oil spill can cause. Clean-up costs alone can exceed this limitation. For 


\section{OCEANA}

example, clean-up costs for the Exxon Valdez spill amounted to $\$ 2$ billion, ${ }^{225}$ and costs for cleaning up the BP Deepwater Horizon disaster were more than \$14 billion in the years directly following the spill. ${ }^{226}$

\section{Natural Disasters and Severe Weather Events Exacerbate Risk of Oil Spills}

In the Gulf of Mexico, oil and gas infrastructure is especially vulnerable to hurricanes. ${ }^{227,228,229}$ In fact, hurricane-caused damage to oil and gas infrastructure is one of the leading causes of oil spills. ${ }^{230,231}$ A 2014 GAO study showed the increasing vulnerability of the United States' energy infrastructure to severe weather driven by climate change. ${ }^{232}$ In 2015, a U.S. Department of Energy report cautioned against investing in new energy infrastructure in hurricane-dominated areas. ${ }^{233}$ Oil and gas industry representatives have acknowledged this issue as well. ${ }^{234,235}$

The Gulf contains extensive oil and gas infrastructure that is vulnerable to hurricanes and storms $-a$ liability to industries and economies that depend on a healthy ocean. As of 2016, there were 2,165 offshore platforms and more than 26,000 miles of underwater pipeline in the Gulf of Mexico. ${ }^{236}$

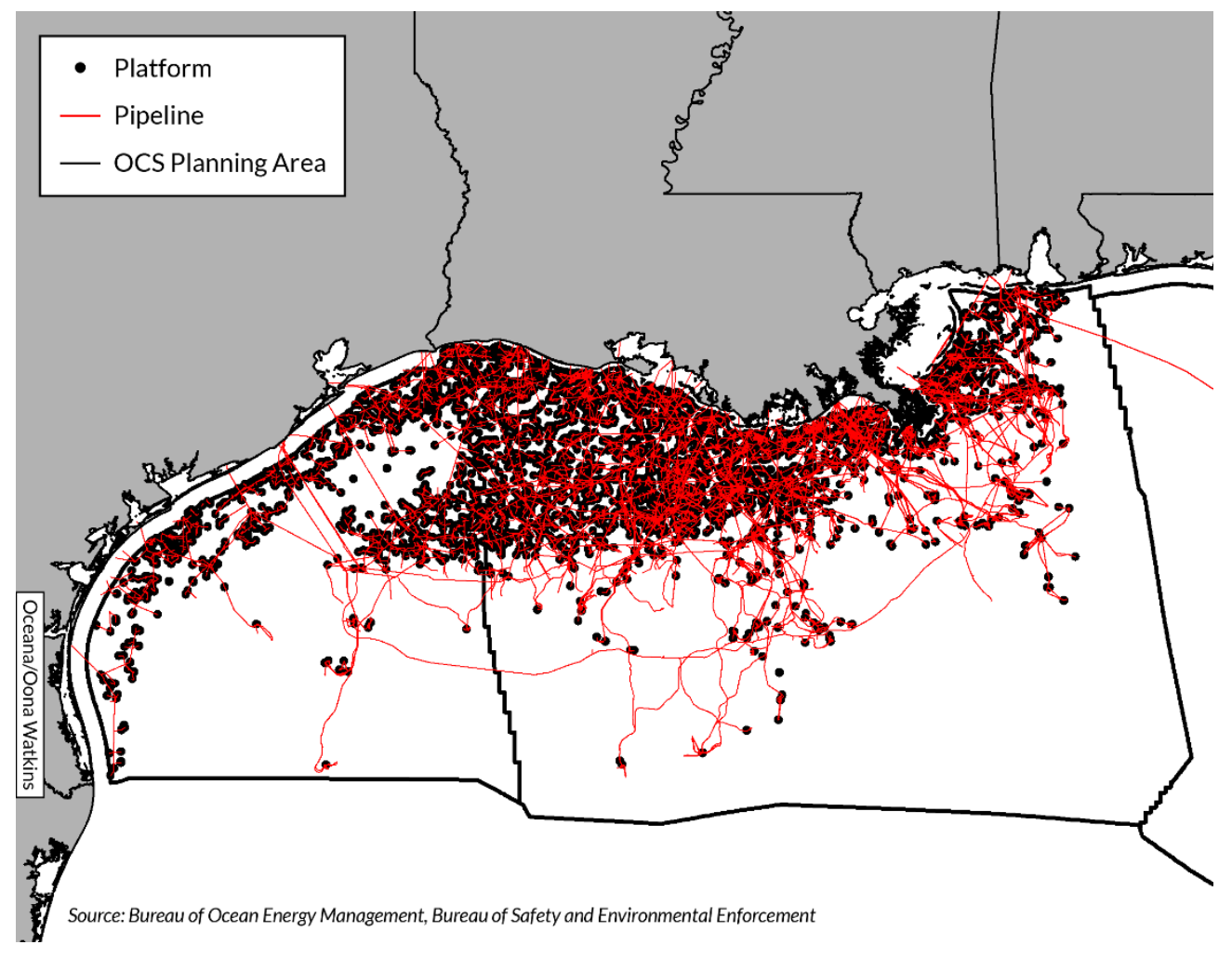

Figure 2. Existing oil and gas infrastructure on the Outer Continental Shelf of the Gulf of Mexico. The data provided by federal agencies includes oil and gas platforms as well as active oil and gas pipelines.

\section{Hurricane Ivan, 2004}

In 2004, a mudslide triggered by Hurricane Ivan sank the Taylor Energy oil platform located off the coast of Louisiana, burying numerous wells deep beneath sub-surface mud. ${ }^{237}$ According to recent court filings by the Department of Justice, these wells are leaking approximately 300 to 700 barrels of oil per day ${ }^{238}-$ much larger than the one-to-55 barrels per day estimate that Taylor Energy originally reported to the Coast 


\section{OCEANA}

Guard. ${ }^{239}$ These leaks amount to roughly 10,000 to 30,000 gallons of oil spilled into the ocean daily. ${ }^{240}$ BSEE has acknowledged that if this spill is left unabated, it could continue for 100 years or more." ${ }^{241}$

After 14 years of leaking, the environmental and economic impacts of the Taylor Energy spill remain largely unknown. ${ }^{242}$ A persistent oil slick coats miles of the ocean surface around the site. ${ }^{243}$ The Southern Environmental Law Center called the Taylor Energy spill one of the most devastating oil spills in history to occur from a hurricane. ${ }^{244}$

\section{Hurricanes Katrina and Rita, 2005}

Occurring in quick succession, Hurricanes Katrina and Rita had devastating impacts on the people, infrastructure and environment of the Gulf of Mexico. ${ }^{245}$ The storms destroyed more than 100 oil and gas platforms and damaged 558 pipelines. ${ }^{246}$ With the predicted increase in hurricane intensity, offshore oil infrastructure will be increasingly in danger of storm damage. ${ }^{247}$

\section{At-Risk Operators May Place Enormous Financial Burden on Public}

As of April 2017, 449 out of 2,104 active facilities in the Gulf were operated by financially at-risk companies. ${ }^{248}$ Financially at-risk offshore oil and gas operators are an enormous financial burden to the public when they are no longer able to fulfill their obligation to properly decommission the numerous wells spanning the Gulf. BSEE has acknowledged that offshore operator bankruptcies are a growing concernespecially since the frequency of bankruptcies has increased due to lower oil prices. ${ }^{249}$

Generally, offshore operators, or lessees, must decommission offshore oil and gas infrastructure when the facilities are no longer useful for operations to prevent potential hazards to vessel traffic and the environment. ${ }^{250,251,252}$ Proper decommissioning requires lessees to permanently plug all wells, remove all platforms and other structures, decommission all pipelines, and clear the seafloor of all obstructions created by the lease and pipeline operations. ${ }^{253}$ To ensure this infrastructure is properly decommissioned, lessees are required to provide financial assurances to cover the costs. ${ }^{254}$

Decommissioning costs can amount to tens of millions of dollars per structure for deep water activitiesdue to the high pressure and great depths involved in deep water drilling. ${ }^{255}$ In 2015 , the GAO evaluated BOEM's financial assurances procedures and found that the procedures posed financial risks to the federal government. ${ }^{256}$ At the time, BOEM required lessees to post a supplemental bond to cover their decommissioning liability, but this bond requirement could be waived if BOEM determined that the lessee had the financial means to meet their decommission obligations by passing a financial strength test. ${ }^{257}$ The GAO found that as of October 2015, BOEM had forgone requiring supplemental bonds for approximately $\$ 33$ billion in decommissioning liabilities in the Gulf of Mexico. ${ }^{258}$

Based on this assessment, BOEM revised its financial assurances procedures and required additional security for sole liability lessees the following year. ${ }^{259}$ However, in 2017, after President Trump called on BOEM to reconsider its financial assurances procedures, ${ }^{260}$ BOEM delayed the implementation of these new procedures and rescinded the requirement that sole liability lessees provide additional security. ${ }^{261}$ As a result, BOEM's financial assurance procedures remain inadequate.

Even though many oil companies possess vast financial resources and are unlikely to default on decommissioning obligations, many financially-secure oil companies reportedly sell off their aging 


\section{OCEANA}

properties to smaller independent companies that are often at a much higher risk of default. ${ }^{262}$ Allowing financially vulnerable lessees to operate without financial guarantees that they can meet their decommissioning obligations puts the federal government and the American taxpayer at risk of footing the bill. If a company cannot afford to safely decommission its facility, it should not be permitted to operate in our public waters.

\section{President Trump Dismantles Offshore Drilling Safety Measures}

\section{Complete Reversal in Offshore Energy Policy}

In a drastic reversal of offshore energy policy, President Trump set out to dismantle important offshore safety regulations put in place following the Deepwater Horizon disaster. ${ }^{263}$ In March 2017, President Trump issued Executive Order 13783, directing federal agencies to "suspend, revise, or rescind [regulations] that unduly burden the development of domestic energy resources beyond the degree necessary to protect the public interest." 264 Shortly thereafter, President Trump issued another executive order that directed the Secretary of the Interior to review and consider revising several regulations affecting offshore oil and gas operations. ${ }^{265}$ As a result, BSEE is rolling back offshore safety measures under the guise that these rules are overly burdensome to industry and do not provide meaningful safety benefits. ${ }^{266}$

One of these rules has already been rolled back. The Production Safety Systems Rule was meant to "play a critical role in protecting workers and the environment" during oil production. ${ }^{267}$ In 2018, BSEE removed several important safety requirements pursuant to President Trump's agenda. In particular, certain safety and pollution prevention equipment is no longer required to undergo review by an independent third-party or be designed to function under the "most extreme conditions." ${ }^{268}$ The specification that calls for mechanical and electrical systems to be reviewed, approved and stamped by a registered professional engineer was removed. ${ }^{269}$ BSEE originally updated this rule in 2016 because of a need to keep pace with offshore oil and gas production that has moved into ever deeper waters and employs highly intricate production technology. ${ }^{270}$ Instead of allowing the updated production requirements to take effect, BSEE removed these safety measures, which allow offshore oil and gas activities to continue without adequate safety measures, even as they move into deeper and riskier depths.

The Well Control Rule is another safety measure at risk of being rolled back. After six years of extensive investigation into both the causes of the BP Deepwater Horizon disaster, as well as vulnerability across the drilling industry, BSEE issued the final Well Control Rule in April 2016. ${ }^{271}$ The rule was intended to prevent a repeat of the BP disaster and required additional maintenance and inspection of blowout preventers. ${ }^{272}$ Recently proposed revisions are slated to greatly diminish several key provisions of the Well Control Rule.

\section{Removal of BSEE Approved Verification Organizations}

Under the original Well Control Rule, BSEE Approved Verification Organizations (BAVOs) were charged with certifying that inspections, maintenance and drilling operations are being conducted in a safe manner. ${ }^{273}$ BSEE alone has the power to authenticate and approve third-party verification entities as BAVOs. This additional layering of oversight was added to avoid industry influence, preserve objectivity and promote accountability. ${ }^{274}$ The proposed revision would remove agency oversight and allow industry operators to choose the entity evaluating the safety of their own equipment. ${ }^{275}$ 


\section{OCEANA}

Current regulations require that a default safe drilling margin be maintained during drilling ${ }^{276}-$ a key parameter designed to reduce the likelihood of a loss of well control. BSEE is considering whether the current drilling margin (based on weight) - a key pressure reading that helps prevent loss of well control should be revised or removed. ${ }^{277}$ BSEE asserts that this change will better accommodate industry with a supposedly flexible case-by-case approach, but points to no set criteria to achieve this approach. ${ }^{278}$ While the National Commission recommended moving to a holistic approach to risk management for individual facilities, it indicated that it should be supplemented with prescriptive safety and pollution-prevention standards. ${ }^{279}$

\section{Weakening of Real-Time Monitoring Requirements}

Currently, real-time monitoring measures require onshore personnel to monitor offshore well operations in real time to help rig personnel conduct their operations safely and aid in identifying potential issues before they become critical. ${ }^{280}$ BSEE's proposed changes undermine critical safety measures by removing the requirement that drilling operators feed real-time data obtained from the well to the operator's observers onshore. ${ }^{281}$ In doing so, BSEE is crippling the accountability measures put in place to serve as a necessary "additional pair of eyes" to ensure safety during drilling operations. ${ }^{282}$

The current approach is necessary to ensure all companies utilize two technical teams, one offshore and one onshore, to provide the redundancy needed to increase safety during risky offshore operations. This need for industry accountability was reinforced by several reports on the disaster and led to the inclusion of real-time monitoring requirements in the original Well Control Rule. ${ }^{283}$ Requiring real-time monitoring measures was a key improvement in offshore safety following the BP Deepwater Horizon disaster.

\section{Blowout Preventer System Testing Requirements}

Under the Well Control Rule, blowout preventer systems are subject to various testing requirements to ensure they are working properly. ${ }^{284}$ These are the safety features specifically aimed at ensuring spills like BP Deepwater Horizon do not happen again. BSEE proposes to drastically reduce the frequency of blowout preventer testing and to remove the requirements that drilling operators submit blowout preventer test results to BSEE if an agency employee is not available to witness the testing. ${ }^{285}$

Further, proposed changes include a reduction in the duration of blowout preventer testing for certain high pressure tests from 30 minutes to only 5 minutes, ${ }^{286}$ which is likely not nearly long enough to determine if the blowout preventer will operate as intended. ${ }^{287}$ Additionally, these pressure tests would reduce the testing pressure to only $1,000 \mathrm{psi}^{288}$ instead of requiring the blowout preventer to be tested at $500 \mathrm{psi}$ greater than the calculated maximum anticipated surface pressure in the original rule. ${ }^{289}$ An arbitrary 1,000 psi requirement is not sufficient to accurately determine whether the blowout preventer will withstand the pressure of a blowout, and, as previously discussed, blowout preventers are not required to be tested under extreme conditions that simulate those in the real world. These safety and oversight measures are critically important to prevent another devastating blowout and weakening them makes another disaster more likely. Testing blowout preventers to ensure reliable and consistent performance under realistic conditions will help improve safety. Reduced testing will only increase risk. 


\section{OCEANA}

BSEE estimates that the proposed safety rollbacks will save the offshore oil and gas industry about $\$ 824$ million over 10 years. ${ }^{290}$ Focusing on industry cost-savings, ${ }^{291}$ however, entirely disregards the safety and environmental benefits the rule was intended to provide in the first place. Moreover, BP's estimated their losses due to the Deepwater Horizon spill amounted to over $\$ 60$ billion, ${ }^{292}$ more than 70 times the estimated 10-year savings from decreasing safety standards.

BSEE's mandate is to "promote safety, protect the environment and conserve offshore resources." Instead of following its mission, BSEE is clearly focused on short-term cost savings for the industry. By weakening key provisions, BSEE is relinquishing its responsibility to ensure that oil and gas exploration and development activities are conducted in the safest manner possible and is offering the industry unfettered discretion to dictate its own lax safety standards. As a result, the oil industry is less safe than before.

The Trump administration continues to try to weaken offshore oil and gas safety measures. Recently, President Trump directed DOI to consider revising other measures that were issued to improve offshore oil and gas operations, including BSEE's Arctic Drilling Rule and BOEM's financial assurances procedures. ${ }^{293}$ To date, BOEM has delayed the implementation of its much-needed updated financial assurances procedures ${ }^{294}$ and BSEE's potential revisions to the Arctic Drilling Rule are still pending. ${ }^{295}$ The Arctic Drilling Rule, focused on OCS exploratory drilling from floating vessels on the Arctic OCS, requires companies to "ensure proper internal controls and planning for oil spill prevention, containment and responses." ${ }^{296}$ In particular, operators are required to have access to a secondary rig capable of drilling a relief well within the same drilling season. ${ }^{297}$

Congress should not allow offshore oil drilling in the Arctic Ocean unless or until there is a proven way to clean up an oil spill and respond to accidents in the ever-changing conditions of icy Arctic waters. This includes adequate response resources, infrastructure, facilities and other elements as part of a realistic plan to respond effectively and quickly to a spill. Any such plan should have contingencies for the known difficulties of traveling to and working in the Arctic, including weather (e.g., fog, ice, wind and darkness), lack of deep water ports and other factors that can make it incredibly challenging to land a plane or move a vessel in the Arctic. Additional challenges to consider include the complex actions needed to locate, contain and attempt to recover spilled oil. Any such response plan should also anticipate the expanded infrastructure needs for housing, food or other essential facilities required to support the necessary personnel who would need to be based out of the Arctic to address any spill or accident, potentially for an extended period of time.

The government is attempting to undercut critical oversight measures while simultaneously expanding oil and gas leasing on the OCS. ${ }^{298}$ If allowed, this would represent the largest expansion of offshore oil exploration and drilling in our nation's publicly owned waters. ${ }^{299}$ Weakening offshore safety measures while expanding offshore drilling activities is wrong and shortsighted.

\section{Conclusion}

Systemic safety failures discovered in the wake of the BP Deepwater Horizon disaster have not been remedied and continue to put the public and environment at unacceptable risk of another devastating oil spill. Moreover, the Trump administration is proposing to radically expand offshore drilling to nearly all U.S. waters while simultaneously rolling back key offshore drilling safety standards that are already in place. The combination of gutting existing safeguards and rapidly expanding drilling operations to new areas is a 


\section{OCEANA}

recipe for disaster. Our oceans, and those who rely on and enjoy them, deserve better.

We recommend President Trump reverse course and direct his administration to reject policy proposals to expand offshore drilling to new areas, cease efforts to slash offshore safety rules, and implement and/or restore safety reforms proposed after the BP Deepwater Horizon disaster. These steps are urgently needed. Additionally, areas with current operations still face ongoing risk and impacts from this unsafe and poorly regulated industry. Therefore, to reduce the continued harm to human safety and the environment, Oceana has the following recommendations:

- President Trump should direct his administration to halt all efforts to expand offshore drilling activities to new areas and abandon attempts to weaken safety regulations.

- BOEM should exclude all new areas from future offshore leasing plans.

- BSEE should restore the safety measures it removed from the Production Safety Systems Rule.

- BSEE should reject proposals to weaken the Well Control Rule.

- DOI should prohibit further leasing in the Arctic seas and halt all efforts to weaken the Arctic Drilling Rule.

- BOEM should fully implement its revised financial assurances procedures to ensure that offshore oil and gas infrastructure can be properly decommissioned.

- BSEE should seek transformative changes to industry's safety culture through greater inspections and enforcement and by reducing reliance on industry-written standards.

- BSEE must improve its inspection and oversight capacity and reduce regulatory reliance on industry-written standards.

- BSEE should increase inspections and develop procedures to effectively enforce safety violations and improve its oversight measures to fulfill its mandate.

- BSEE should make the process of granting departures and alternative compliance transparent and accountable to the public.

- BSEE should act as a truly independent agency without industry influence over safety rules and standards.

- BSEE should require blowout preventers be tested often and under extreme real-world conditions.

- Alternative blowout prevention strategies should also be explored. BSEE should evaluate the efficacy of drilling relief wells concurrent with exploratory wells as a method to prevent the loss of well control.

- Congress must substantially increase financial penalties for safety violations to ensure that risktaking is no longer profitable.

- The offshore industry should implement the National Commission's recommendation for an independent organization that is focused solely on safety without industry influence.

- The industry should tackle the problem of potential underreporting of incidents and injuries, but also set higher safety standards to reduce injury and death rates.

- The industry should improve training for operators, including simulated-based training, that may help reduce operator error. Effective oversight of this industry is still needed to ensure errors are avoided.

- Congress must require accurate oil spill reporting, establish industry-specific penalties for under- 


\section{OCEANA}

reporting, increase federal resources and research new clean-up technologies.

- The Environmental Protection Agency should update its oil spill reporting requirements so that oil spill estimates are updated within seven days of initial reporting, and on an ongoing basis until spill volume is contained, to verify the accuracy of spill estimates and to ensure adequate resources are allocated for clean-up response.

- Congress should increase BSEE funding for oil spill research and clean-up methods.

- BOEM should require that offshore operators have sufficient up-front financial resources for clean-up costs before allowing drilling.

- The United States must shift to renewable energy sources like offshore wind.

- Congress must enact measures to help stimulate increased investment in renewable energy sources like offshore wind to allow the nation to shift away from offshore oil drilling.

\section{Acknowledgements}

The authors would like to give special thanks to Lois Epstein, P.E. of The Wilderness Society; Dr. Donald Boesch of University of Maryland Center for Environmental Science and former member of the National Commission on the BP Deepwater Horizon Oil Spill and Offshore Drilling; Elizabeth Klein of State Energy \& Environmental Impact Center NYU School of Law; and John Amos of SkyTruth for their contributions during the development and review of this report.

We would also like to give sincere thanks to the many Oceana team members who helped with this report, including Loryn Baughman, Dustin Cranor, Dr. Sarah Giltz, Lara Levison, Beth Lowell, Dr. Kathryn Matthews, Michael Messmer, Patrick Mustain, Nancy Pyne, Jacqueline Savitz and Oona Watkins. 


\section{OCEANA}

\section{$\underline{\text { References }}$}

${ }^{1}$ Nat'I Comm'n on the BP Deepwater Horizon Oil Spill and Offshore Drilling, DeEP WATER THE GULF OIL DISASTER AND THE FUTURE OF OfFSHORE DRILLING REPORT TO THE PRESIDENT 217 (2011), https://www.gpo.gov/fdsys/pkg/GPO-OILCOMMISSION/pdf/GPOOILCOMMISSION.pdf.

${ }^{2}$ NOAA Incident News, Santa Barbara Well blowout, https://incidentnews.noaa.gov/incident/6206\#! (last visited Apr. 8, 2019) (Under the Other Special Interest Issues section: "The accident may not have occurred if Union Oil had put steel casing around the hole to a depth of 2,000 feet. Even though this is a known unstable earthquake fault area, Union had received a waiver from Federal officials to case the well to only 238 feet.").

${ }^{3}$ Outer Continental Shelf Oil and Gas Strategy and Implications of the Deepwater Horizon Rig Explosion: Parts 1 and 2 - Oversight Hearing Before the Comm. on Natural Res. U.S. House of Representatives, 11 $1^{\text {th }}$ Cong. 143-144 (2010), https://www.govinfo.gov/content/pkg/CHRG-111hhrg56675/pdf/CHRG-111hhrg56675.pdf.

${ }^{4} \mathrm{Nat}$ 'I Comm'n on the BP Deepwater Horizon Oil Spill and Offshore Drilling, supra note 1, at 28-30, 125 \& 223.

${ }^{5} \mathrm{Nat}$ 'I Academies of Sciences, Engineering, and Medicine, STRENGTHENING THE SAFETY CULTURE OF THE OFFSHORE OIL AND GAS INDUSTRY 5, 14-15 (2016), https://www.nap.edu/catalog/23524/strengthening-the-safety-culture-of-the-offshore-oil-and-gas-industry. ${ }^{6}$ Office of Inspector Gen., U.S. Dep't of the Interior, REPORT NUMBER: 14-0051, SUMMARY: INVESTIGATION OF FALSIFIED BLOWOUT PREVENTER TEST CHART (2018), https://www.doioig.gov/sites/doioig.gov/files/InvestigativeSummary ERTBOPFalsification.pdf. 7 David Hilzenrath, When All Hell Breaks Loose: Years After Deepwater Horizon, Offshore Drilling Hazards Persist, Project on Gov't Oversight, Dec. 6, 2018, https://www.pogo.org/investigation/2018/12/when-all-hell-breaks-loose-years-after-deepwaterhorizon-offshore-drilling-hazards-persist/.

${ }^{8}$ See Nat'I Comm'n on the BP Deepwater Horizon Oil Spill and Offshore Drilling, supra note 1, at 71-75, 225.

${ }^{9}$ See API-IADC-NOIA-IPAA-OOC-PESA-USOGA, FINAL-Proposed-WCR-Comments-08062018 1 (Aug. 6, 2018), https://www.regulations.gov/document?D=BSEE-2018-0002-45174.

${ }^{10}$ See Nat'I Comm'n on the BP Deepwater Horizon Oil Spill and Offshore Drilling, supra note 1, at vi-vii.

${ }^{11}$ NOAA, Deepwater Horizon Oil Spill 2010 - Sea Turtles, Dolphins, and Whales, https://www.fisheries.noaa.gov/national/marine-lifedistress/deepwater-horizon-oil-spill-2010-sea-turtles-dolphins-and-whales (last updated Aug. 9, 2018).

${ }_{12}$ Gulf Spill Restoration, Affected Gulf Resources, https://www.gulfspillrestoration.noaa.gov/affected-gulf-resources, (last visited Apr. 8, 2019).

${ }^{13}$ Nat'I Comm'n on the BP Deepwater Horizon Oil Spill and Offshore Drilling, supra note 1, at 191-195.

${ }^{14}$ NOAA Office of Response and Restoration, Assessing the Impacts from Deepwater Horizon (Apr. 4,

2017), https://response.restoration.noaa.gov/about/media/assessing-impacts-deepwater-horizon.html.

${ }^{15}$ Nat'I Comm'n on the BP Deepwater Horizon Oil Spill and Offshore Drilling, supra note 1, at vi.

${ }^{16} / d$. at 122.

${ }^{17}$ See generally National Commission on the BP Deepwater Horizon Oil Spill and Offshore Drilling, supra note 1.

${ }^{18}$ Bureau of Safety and Envtl. Enforcement, Reforms since the Deepwater Horizon Tragedy (Jul. 25, 2016), https://www.bsee.gov/reforms-since-deepwater-horizon.

${ }^{19}$ See generally U.S. Gov't Accountability Office, OIL AND GAS MANAGEMENT INTERIOR'S BUREAU OF SAFETY AND ENVIRONMENTAL Enforcement Restructuring Has Not Addressed Long-Standing OVersight Deficiencies (2016), https://www.gao.gov/assets/680/675099.pdf.

${ }^{20}$ U.S. Chemical Safety Bd., The U.S. Chemical Safety Board's Investigation into the Macondo Disaster Finds Offshore Risk Management and Regulatory Oversight still Inadequate in Gulf of Mexico (Apr. 13, 2016), https://www.csb.gov/the-us-chemical-safety-boardsinvestigation-into-the-macondo-disaster-finds-offshore-risk-management-and-regulatory-oversight-still-inadequate-in-gulf-ofmexico/.

${ }^{21}$ See generally U.S. Chemical Safety Bd., MACONDO INVESTIGATION REPORT (Apr. 20, 2016), https://www.csb.gov/macondo-blowoutand-explosion/.

22 Bureau of Safety and Envtl. Enforcement, About Us, https://www.bsee.gov/who-we-are/about-us (last visited Apr. 8, 2019).

${ }^{23}$ U.S. Gov't Accountability Office, supra note 19.

${ }^{24}$ Email from Lois Epstein, Engineer \& Arctic Program Director, The Wilderness Society to Madeline Voitier, Policy and Legal Specialist, Oceana (Apr. 9, 2019, 16:50 EST) (on file with author).

${ }^{25}$ See Bureau of Safety and Envtl. Enforcement, ANNUAL REPORT 2016, 15-18, 24 (2016), https://www.bsee.gov/sites/bsee.gov/files/bsee 2016 annual report v6b.pdf (There was far more offshore activity in the Gulf of Mexico region, requiring inspections, than other OCS region).

${ }^{26}$ Bureau of Safety and Envtl. Enforcement, BSEE Inspection Program (Jan. 2018), https://www.boem.gov/NP-BSEE-InspectionProgram-Fact-Sheet/. 


\section{OCEANA}

2743 U.S.C. $\S 1348(c)(1)-(2)$.

28 U.S. Dept. of Interior, Budget JustifiCATIONS AND PERFORMANCE INFORMATION FISCAL YEAR 2020, BUREAU OF SAFETY AND

ENVIRONMENTAL ENFORCEMENT 52 (2019), https://www.bsee.gov/sites/bsee.gov/files/budget-justifications//fy2020-bseejustification.pdf.

${ }^{29}$ U.S. Gov't Accountability Office, supra note 19.

${ }^{30}$ See U.S. Gov't Accountability Office, supra note 19, at 10-12.

31U.S. Gov't Accountability Office, REPORT TO CONGRESSIONAL COMMITTEES HIGH-RISK SERIES PROGRESS ON MANY HIGH-RISK AREAS, WHILE SUBSTANTIAL EFFORTS NEEDED ON OTHERS 23 (2017), https://www.gao.gov/assets/690/682765.pdf.

${ }^{32}$ See generally U.S. Government Accountability Office, TESTIMONY BEFORE THE SUBCOMMITTEE ON THE INTERIOR ENERGY, AND

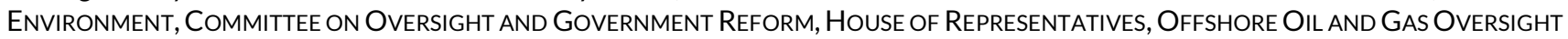

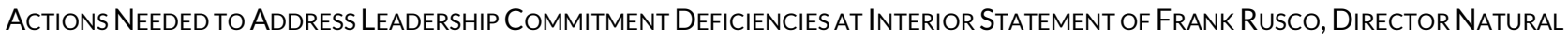
RESOURCES AND ENVIRONMENT (2017), https://www.gao.gov/assets/690/683473.pdf.

${ }^{33}$ U.S. Gov't Accountability Office, supra note 31, at 21.

34 U.S. Gov't Accountability Office, supra note 31, at 23-25.

35 U.S. Gov't Accountability Office, REPORT to CONGRESSIONAL COMMITTEES HIGH-RISK SERIES SUBSTANTIAL EFFORTS NEEDED TO ACHIEVE GREATER PROGRESS ON HIGH-RISK AREAS 107-108 (2019), https://www.gao.gov/assets/700/697245.pdf.

${ }^{36}$ Nat'l Academies of Sciences Engineering Medicine, Project Information Review and Update of Bureau of Safety and Environmental Enforcement Offshore Oil and Gas Operations Inspection Program,

https://www8.nationalacademies.org/pa/projectview.aspx?key=49890 (last visited Apr. 9, 2019).

${ }^{37}$ Bureau of Safety and Envtl. Enforcement, BSEE Launches Risk-Based Inspection Program (Mar. 12, 2018), https://www.bsee.gov/newsroom/latest-news/statements-and-releases/press-releases/bsee-launches-risk-based-inspection.

${ }_{38}$ Blowout Preventer Systems and Well Control Revisions, 83 Fed. Reg. 22,128, 22,130 (May 11, 2018), https://www.govinfo.gov/content/pkg/FR-2018-05-11/pdf/2018-09305.pdf.

${ }^{39}$ Blowout Preventer Systems and Well Control Proposed Rule, 80 Fed. Reg. 21,504, 21, 509 and 21,510 (Apr. 17, 2015), https://www.regulations.gov/document?D=BSEE-2015-0002-0001.

${ }^{40}$ Blowout Preventer Systems and Well Control Final Rule, 81 Fed. Reg. 25,888, 25,948 (Apr. 29, 2016), https://www.govinfo.gov/content/pkg/FR-2016-04-29/pdf/2016-08921.pdf.

${ }^{41}$ See 30 C.F.R. § § 250.141-142 and 250.409 (2019).

42 See id.

4330 C.F.R. § 250.141 (2019).

4430 C.F.R. $\S 250.414$ (h) (2019).

45 Deepwater Horizon Joint Investigation Team Report, Appendix I: APD Departures at the Macondo Well Granted by MMS, https://www.bsee.gov/newsroom/library/deepwater-horizon-reading-room/joint-investigation-team-report (last visited Apr. 9 , 2019).

4630 CFR § 250.1721(d) (2019).

47 Deepwater Horizon Joint Investigation Team Report, supra note 45.

${ }^{48}$ Nat'I Comm'n on the BP Deepwater Horizon Oil Spill and Offshore Drilling, supra note 1, at 127 ("MMS approved a number of other requests by BP for deviations on the Macondo well. None of those other approvals appear to have contributed to the blowout. However, they do suggest that the MMS staff did not spend much time deciding whether to grant the requests, which may have been due to the severe funding and staffing shortages in the New Orleans office.").

${ }^{49}$ See Deepwater Horizon Joint Investigation Team, U.S. Dep't of Interior, VolUME II: REPORT REGARDING THE CAUSES OF THE APRIL 20, 2010 MACONDO WELL BLOWOUT. REPORT OF INVESTIGATION 87 (2011), https://www.bsee.gov/newsroom/library/deepwater-horizonreading-room/joint-investigation-team-report.

${ }^{50}$ Ben Lefebvre, Interior hands out nearly 1,700 waivers to offshore drilling safety rules, Politico, Feb. 25, 2019, https://www.politico.com/story/2019/02/25/offshore-drilling-trump-administration-interior-department-1190762.

${ }^{51}$ See id.

52 Id.

53 Id.

54 Reorganization of Title 30: Bureaus of Safety and Envtl. Enforcement and Ocean Energy Management, 76 Fed. Reg. 64,432, 64,432 (Oct. 18, 2011), https://www.boem.gov/76-FR-64432/.

${ }^{55}$ See Bureau of Safety and Envtl. Enforcement, About Us, https://www.bsee.gov/who-we-are/about-us (last visited Apr. 9, 2019).

${ }^{56}$ Blowout Preventer Systems and Well Control Final Rule, 81 Fed. Reg. at 25,888.

57 Blowout Preventer Systems and Well Control Revisions, 83 Fed. Reg. at 22,128.

58 Oil and Gas Production Safety Systems, 81 Fed. Reg. 61,834, 61,834 (Sept. 7, 2016), https://www.gpo.gov/fdsys/pkg/FR-201609-07/pdf/2016-20967.pdf. 


\section{OCEANA}

59 Oil and Gas Production Safety Systems, 83 Fed. Reg. 49,216, 49,216 (Sept. 28, 2018), https://www.gpo.gov/fdsys/pkg/FR-201809-28/pdf/2018-21197.pdf.

60 Jeff Rosen, Section of Administrative LaW and Regulatory Practice, Report to the House of Delegates - Resolution, American Bar Association 3 (2016),

https://www.americanbar.org/content/dam/aba/administrative/administrative law/107a\%20incorporation\%20by\%20reference.a uthcheckdam.pdf.

${ }^{61}$ Nat'I Comm'n on the BP Deepwater Horizon Oil Spill and Offshore Drilling, supra note 1, at 225.

${ }^{62}$ Energy API, About API, https://www.api.org/about (last visited Apr. 9, 2019).

${ }^{63}$ See American Petroleum Institute, Procedures FOR STANDARDS DEVELOPMENT FifTH EdITION 1, 4 (2016),

http://mycommittees.api.org/standards/Reference/API\%20Procedures\%20for\%20Standards\%20Development-2016.pdf.

${ }^{64}$ See id. at 2.

${ }^{65}$ Nat'I Comm'n on the BP Deepwater Horizon Oil Spill and Offshore Drilling, supra note 1, at 225.

${ }^{66}$ Id. at 73-79.

67 Id. at 225 .

68 ld.

${ }^{69}$ Id. (The National Commissions report refers to the Interior Department and more specifically the Minerals Management Service, which was later broken into three agencies including the Bureau of Safety and Environmental Enforcement (BSEE)-BSEE continues to incorporate API standards by reference).

70 Energy API, Login or Create an Account, http://publications.api.org/ (last visited Apr. 9, 2019).

${ }^{71}$ David S. Hilzenrath, Interior Dept Gives Rules Drafted by Oil Industry Force of Law, Project On Gov't Oversight, Aug. 7, 2018, https://www.pogo.org/investigation/2018/08/interior-dept-gives-rules-drafted-by-oil-industry-force-of-law/.

72 See Energy API, supra note 70.

${ }^{73}$ Energy API, Acceptance of Terms, http://publications.api.org/GocCited Disclaimer.aspx (last visited Apr. 9, 2019).

74 David Hilzenrath, Big Oil Rules: One Reporter's Runaround to Access “Public” Documents, Project on Gov't Oversight, Dec. 6, 2018, https://www.pogo.org/investigation/2018/12/big-oil-rules-one-reporters-runaround-to-access-public-documents/.

${ }^{75}$ Energy API, supra note 70.

76 Energy API, Most Popular Titles From API, https://www.techstreet.com/api/popular.html (lasted visited Apr. 9, 2019 ).

77 Blowout Preventer Systems and Well Control Revisions, 83 Fed. Reg. at 22,128.

78 Id.

${ }^{79}$ David S. Hilzenrath, supra note 71.

${ }^{80}$ Nat'I Comm'n on the BP Deepwater Horizon Oil Spill and Offshore Drilling, supra note 1, at 127.

81 Id.

82 Id. at 91.

${ }^{83}$ Id.

84 Id. at 92.

85 Id. at xi.

86 Id. at 114.

${ }^{87}$ Bureau of Safety and Envtl. Enforcement, INVESTIGATION OF LOSS OF WELL CONTROL AND FIRE SOUTH TIMBALIER AREA BLOCK 220, WELL No. A-3 OCS-G 249802 (2013), https://www.bsee.gov/sites/bsee.gov/files/panel-investigation/incident-and-investigations/st220-panel-report9-8-2015.pdf.

${ }^{88}$ See WEST Engineering Services, Inc., Mini Shear Study for U.S. Minerals Management SerVICE, Requisition No. 2-1011-1003, 3 (2002), https://www.bsee.gov/sites/bsee.gov/files/tap-technical-assessment-program//455aa.pdf.

89 Bureau of Safety and Environmental Enforcement, Glossary, https://www.bsee.gov/newsroom/library/glossary (last visited Apr. 9, 2019) (see definition for blowout preventer).

90 See U.S. Chemical Safety Bd., MAcondo InVESTIgATION Report Volume 2 at 17-21 (2014), https://www.csb.gov/macondo-blowoutand-explosion/.

${ }^{91}$ Nat'I Comm'n on the BP Deepwater Horizon Oil Spill and Offshore Drilling, supra note 1, at 114-15.

92 Deepwater Horizon Joint Investigation Team, supra note 49 at 138-9.

${ }^{93}$ Nat'I Comm'n on the BP Deepwater Horizon Oil Spill and Offshore Drilling, supra note 1, at 165.

${ }^{94}$ See Deepwater Horizon Joint Investigation Team, supra note 49 at 140.

95 Det Norske Veritas, Final Report for United StATES DeP'T OF THE INTERIOR BuREAu of OCEAn EnERgy MANAGEMENT, Regulation, AND ENFORCEMENT Forensic EXAMINATION OF DeEPWATER Horizon Blowout PREVEnTER 175-76 (2011),

https://www.scribd.com/document/82838281/TREX-01164.

96 See id. at 177-78.

97 Deepwater Horizon Joint Investigation Team, supra note 49 at 144-5. 


\section{OCEANA}

98 Id. at 207.

99 Blowout Preventer Systems and Well Control Final Rule, 81 Fed. Reg. at 25,894.

100 Blowout Preventer Systems and Well Control Revisions, 83 Fed. Reg. at 22,138-22, 140 ("BSEE believes that, since newer shearing blades can center pipe, it is unnecessary to require a pipe centering mechanism.").

10130 CFR $\S 250.730$ (a) (2019) (requires "the BOP system, not each ram, must be capable of closing and sealing the wellbore at all times under "... anticipated flowing conditions for the specific well conditions ....").

102 Blowout Preventer Systems and Well Control Final Rule, 81 Fed. Reg. at 25,940 ("the BOP system, not each ram, must be capable of closing and sealing the wellbore at all times under "... anticipated flowing conditions for the specific well conditions ..."). 103 U.S. Chemical Safety Bd., supra note 90 at 14.

${ }^{104}$ Bureau of Safety and Envtl. Enforcement, Transcripts- Panel No. 2: What new design requirements are needed to provide assurance that BOPs will cut and seal effectively under foreseeable operating conditions? (May 2012), https://www.bsee.gov/newsroom/latestnews/statements-releases/transcripts.

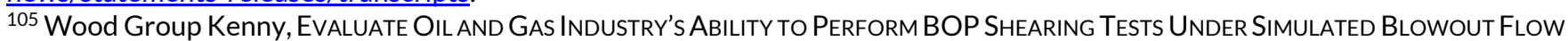
CONDITIONS FINAL REPORT 29 (2015), https://www.bsee.gov/sites/bsee.gov/files/tap-technical-assessment-program/742aa.pdf.

106 Id. at 4.

107 Id. at 29.

108 Id. at 4-5, 18-19.

109 Id. at 29.

110 Id. at 4-5.

${ }^{111}$ See U.S. Chemical Safety Bd., INVESTIgATION RePORT EXECUTIVE SUMMARY - DRILLING RIg EXPLOSION AND FIRE AT THE MACONDO WELL 6-7 (2016), https://www.csb.gov/macondo-blowout-and-explosion/.

112 U.S. Dep't of Transportation, BLowout PREVEntion SAFETy System 2017 ANNUAL Report 1 (2017), https://www.safeocs.gov/2017 WCR Annual Report v4.pdf.

113 Id. at vii.

114 Id. at vii, 6.

115 Id. at 6.

116 Id. at 9-10.

117 Id. at 19.

${ }^{118}$ Bureau of Safety and Envtl. Enforcement, Offshore Incident Statistics, https://www.bsee.gov/stats-facts/offshore-incidentstatistics (last visited Apr. 10, 2019).

${ }_{119}$ API-IADC-NOIA-IPAA-OOC-PESA-USOGA, supra note 9 (Industry requested BSEE changed the BOP equipment testing interval from 14 days to 21 days).

120 See Blowout Preventer Systems and Well Control Revisions, 83 Fed. Reg. at 22,141-22,142.

${ }^{121}$ See U.S. Department of Transportation, supra note 112 at 9.

122 U.S. Chemical Safety Bd., supra note 90 at 36-39.

${ }^{123}$ Deepwater Horizon Joint Investigation Team, supra note 49 at 18.

12430 C.F.R. $\S 250.1403$ (2019).

125 See Bureau of Safety and Envtl. Enforcement, Incidents of Non-Compliance (INCs), https://www.bsee.gov/what-we-do/safetyenforcement/enforcement-tools/incidents-of-non-compliance (last visited Apr. 9, 2019).

${ }^{126}$ Bureau of Safety and Envtl. Enforcement, Civil Penalties Assessments and Appeals, https://www.bsee.gov/what-we-do/safetyenforcement/civil-penalties-assessments-and-appeals (last visited Apr. 9, 2019).

127 U.S. Dep't of the Interior Outer Continental Shelf Safety Oversight Board, REPORT TO SECRETARY OF THE INTERIOR KEN SALAZAR, 1719 (2010), https://www.doi.gov/sites/doi.gov/files/migrated/news/pressreleases/upload/OCS-Safety-Oversight-Board-

Report.pdf.

${ }_{128}$ Bureau of Safety and Envtl. Enforcement, ANNUAL REPORT 2016, 25 (2016),

https://www.bsee.gov/sites/bsee.gov/files/bsee 2016 annual report v6b.pdf.

129 ld.

${ }^{130}$ Deepwater Horizon Joint Investigation Team, supra note 49 at 18.

13130 C.F.R. $\S 250.1403$ (2019).

132 Nick Cunningham, Oil Majors See Profits Spike, Exxon Lags Behind, Oilprice.com, May 1, 2018, https://oilprice.com/Energy/EnergyGeneral/Oil-Majors-See-Profits-Spike-Exxon-Lags-Behind.html.

${ }^{133}$ See Nat'I Comm'n on the BP Deepwater Horizon Oil Spill and Offshore Drilling, supra note 1, at 114.

134 See id.

135 U.S. Dept. of Interior, Bureau of Safety and Envtl. Enforcement Gulf of Mexico Region, ACCIDENT INVESTIGATION REPORT (2019), https://www.bsee.gov/sites/bsee.gov/files/ss349-wtoffshore-25-august-2018.pdf. 


\section{DCEANA}

136 U.S. Dept. of Interior, Bureau of Safety and Envtl. Enforcement Gulf of Mexico Region, ACCIDENT INVESTIGATION REPORT (2018), https://www.bsee.gov/sites/bsee.gov/files/mc-778-bp-16-oct-2017.pdf

137 U.S. Dept. of Interior, Bureau of Safety and Envtl. Enforcement Gulf of Mexico Region, ACCIDENT INVESTIGATION REPORT (2018), https://www.bsee.gov/sites/bsee.gov/files/gb-128-shell-8-nov-2017.pdf.

138 MAERSK TRAINING, Welcome to Maersk Training in Houston, https://www.maersktraining.com/houston\#bookingarea, (last visited Apr. 9, 2019).

${ }^{139}$ See Bureau of Safety and Environmental Envtl., Safety Enforcement, https://www.bsee.gov/what-we-do/safety-enforcement (last visited Mar. 6, 2019).

140 Nat'I Comm'n on the BP Deepwater Horizon Oil Spill and Offshore Drilling, supra note 1, at 217.

${ }^{141}$ See National Academies of Sciences, Engineering, and Medicine, supra note 5, at 4- 5 ("The offshore industry is gradually changing from one with a risk-taking attitude to one in which anyone can raise a safety concern or stop work on a job because of safety issues. As with many industries, however, a blaming culture still exists in the offshore industry, as well as a lack of systems thinking that results in focusing on the immediate proximal causes of a safety failure (such as human error) rather than system causes, including culture").

142 API-IADC-NOIA-IPAA-OOC-PESA-USOGA, supra note 9, at 1-4.

${ }_{143}$ Revisions to Safety and Environmental Management Systems, 78 Fed. Reg. 20,423, 20,424 \& 20,427 (Apr. 5, 2013), https://www.govinfo.gov/content/pkg/FR-2013-04-05/pdf/2013-07738.pdf.

${ }^{144}$ See Nat'I Comm'n on the BP Deepwater Horizon Oil Spill and Offshore Drilling, supra note 1, at 228.

145 Bureau of Safety and Envtl. Enforcement, Safety and Environmental Management Systems - SEMS,

https://www.bsee.gov/resources-and-tools/compliance/safety-and-environmental-management-systems-sems (last visited Mar.

26, 2019).

14630 C.F.R. $\S 250.1901$ (2019).

147 Bureau of Envtl. Enforcement, Safety and Environmental Management Systems (SEMS) Fact Sheet, https://www.bsee.gov/sites/bsee.gov/files/fact-sheet/safety/sems-ii-fact-sheet.pdf (last visited Apr. 9, 2019 ).

${ }_{148}$ Bureau of Safety and Environmental Enforcement, Safety and Environmental Management Systems (SEMS) Fact Sheet, https://www.bsee.gov/sites/bsee.gov/files/fact-sheet/safety/sems-ii-fact-sheet.pdf (last visited Apr. 9, 2019).

${ }_{149}$ Ctr. for Offshore Safety, , ANNUAL PERFORMANCE REPORT FOR 2017 RePORTING YEAR 9 (2018), https://www.centerforoffshoresafety.org/ /media/COS/Annual\%20Performance\%20Reports/2017\%20APR\%20FINAL.pdf.

150 Nat'I Comm'n on the BP Deepwater Horizon Oil Spill and Offshore Drilling, supra note 1, at 239.

151 Id. at 241.

152 Id.

${ }^{153}$ American Petroleum Institute, API response to Deepwater Horizon report: 'We've made progress to improve safety,' gCaptain, Jan. 12, 2011, https://gcaptain.com/response-deepwater-horizon-report/.

${ }^{154}$ Nat'I Comm'n on the BP Deepwater Horizon Oil Spill and Offshore Drilling, supra note 1, at 241.

155 National Academies of Sciences, Engineering, and Medicine, BeYOND COMPLIANCE: STRENGTHENING THE SAFETY CULTURE OF THE OFFSHORE OIL AND GAS INDUSTRY 15-17 (2016), https://www.nap.edu/catalog/23662/beyond-compliance-strengthening-the-safetyculture-of-the-offshore-oil-and-gas-industry.

${ }_{156}$ Id. at 15-16 (noting COS membership is open to all companies operating on the U.S. Outer Continental Shelf, but, as of May 2016, only 14 operators, 6 drilling contractors, and 10 service or equipment provided had joined).

157 See id. at 16.

158 See generally Ctr. for Offshore Safety, supra note 149 (providing an example of a performance report audit).

159 National Academies of Sciences, Engineering, and Medicine, supra note 155, at 15-16.

160 See id at 22-27.

${ }^{161}$ Scott Eustis et al., OIL AND GAS IN THE GULF OF MEXICO, Gulf Restoration Network 2 (2018).

162 Bureau of Safety and Environmental Enforcement, supra note 118.

163 Id.

164 See Bureau of Safety and Envtl. Enforcement, PeRfORMANCE BASED RISK INSPECTION (PBRI) LIFTING SAFETY 2, 4-15 (2018),

https://www.bsee.gov/sites/bsee.gov/files/lifting-safety-pbri-report-public-05212018-rev3.pdf.

165 Bureau of Safety and Envtl. Enforcement, BSEE Issues Safety Alert Based on Inspection Pilot Findings (Jan. 5, 2018), https://www.bsee.gov/newsroom/latest-news/statements-and-releases/press-releases/bsee-issues-safety-alert-based-on.

166 Bureau of Safety and Envtl. Enforcement, SAFETY ALERT Gas Release Hazards Identified by BSEE (Jan. 5, 2018), https://www.bsee.gov/sites/bsee.gov/files/safety-alerts//safety-alert-328-gas-release-hazards-identified-by-bsee.pdf.

${ }^{167}$ Bureau of Safety and Envtl. Enforcement, Incident of Non-Compliance (INCS) Online Query, https://www.data.bsee.gov/Company/INCs/Default.aspx (last updated Apr. 7, 2019) (Queried timeframe between Jan. 1, 2019 to Apr. 10, 2019). 


\section{OCEANA}

${ }^{168}$ Bureau of Safety and Envtl. Enforcement, Incident of Non-Compliance (INCS) Online Query, https://www.data.bsee.gov/Company/INCs/Default.aspx (last updated Apr. 7, 2019) (Queried timeframe between Jan. 1, 2018 to Dec. 31, 2018).

${ }^{169}$ Bureau of Safety and Envtl. Enforcement, Enforcement Tools, https://www.bsee.gov/what-we-do/safetyenforcement/enforcement-tools (last visited Apr. 9, 2019).

170 Dept. of Interior, supra note 28, at 39.

${ }^{171}$ Bureau of Safety and Envtl. Enforcement, Glossary https://www.bsee.gov/newsroom/library/glossary\#Outer continental shelf (last visited Apr. 9, 2019) (see definition for Incident of Noncompliance (INC)).

172 Office of Inspector Gen., U.S. Dep't of the Interior, SUMMARY: INVESTIGATION OF FALSIFIED BLOWOUT PREVENTER TEST CHART (2018), https://www.doioig.gov/sites/doioig.gov/files/InvestigativeSummary ERTBOPFalsification.pdf.

173 Office of Inspector Gen., U.S. Dep't of the Interior, SUMMARY: INVESTIGATION OF FALSIFIED SAFETY TEST ON AN OFFSHORE DRILLING RIG (2014), https://www.doioig.gov/sites/doioig.gov/files/InvestigativeSummary OffshoreDrillingRigFalsifiedSafetyTest.pdf.

${ }^{174}$ Nat'I Comm'n on the BP Deepwater Horizon Oil Spill and Offshore Drilling, supra note 1, at 251.

175 Nat'I Comm'n on the BP Deepwater Horizon Oil Spill and Offshore Drilling, supra note 1, at 225 (This measurement was determined based on per person hours worked).

176 Nat'I Comm'n on the BP Deepwater Horizon Oil Spill and Offshore Drilling, supra note 1, at 251.

177 Krystal L. Mason et al., Occupational Fatalities During the Oil and Gas Boom - United States, 2003-2013, Centers for Disease

Control and Prevention (May 29, 2015), https://www.cdc.gov/mmwr/preview/mmwrhtml/mm6420a4.htm.

178 Bureau of Safety and Environmental Enforcement, supra note 118.

179 NOAA Office of Response and Restoration, Largest Oil Spills Affecting U.S. Waters Since 1969,

https://response.restoration.noaa.gov/oil-and-chemical-spills/oil-spills/largest-oil-spills-affecting-us-waters-1969.html (last visited Apr. 10, 2019).

180 U.S. Coast Guard, National Response Center, http://nrc.uscg.mil// (last visited Apr. 9, 2019).

${ }^{181}$ Nat'I Comm'n on the BP Deepwater Horizon Oil Spill and Offshore Drilling, supra note 1, at 173-191.

182 Washington Sea Grant, Education to Prevent Small Oil Spills, University of Washington,

https://wsg.washington.edu/wordpress/wp-content/uploads/SOSFactSheetV2.pdf (last visited Apr. 10, 2019).

183 Nat'I Comm'n on the BP Deepwater Horizon Oil Spill and Offshore Drilling, supra note 1, at 114-115.

${ }^{184}$ NOAA Damage Assessment, Remediation, and Restoration Program, Taylor Energy, (last updated Nov. 27, 2018),

https://darrp.noaa.gov/oil-spills/taylor-energy.

185 NOAA Office of Response and Restoration, Like a Summer Blockbuster, Oil Spills and Hurricanes Cane Take the Nation By Storm (May 29, 2015), https://response.restoration.noaa.gov/about/media/summer-blockbuster-oil-spills-and-hurricanes-cantake-nation-storm.html.

186 See Bureau of Safety and Envtl. Enforcement, Bureau of Ocean Energy Management, 2016 UPDATE OF OCCURRENCE RATES FOR OFFSHORE OIL SPILLS 22-25 (2016), https://www.bsee.gov/sites/bsee.gov/files/osrr-oil-spill-response-research//1086aa.pdf.

187 See generally id. (analyzing all aspects of offshore oil and gas operations in which oil spills occur).

188 See generally Bureau of Safety and Envtl. Enforcement, SUMMARY OF RESULTS FOR OCS PERFORMANCE MEASURES: 2007-2017, https://www.bsee.gov/sites/bsee.gov/files/summary-of-ocs-performance-measures-2007-2017.pdf (last visited Apr. 10, 2019).

${ }_{189}$ Bureau of Safety and Envtl. Enforcement, supra note 186, at 13.

190 Samira Daneshgar Asl et al, Chronic, Anthropogenic Hydrocarbon Discharges in the Gulf of Mexico, 129 Deep Sea Research Part II187,187, 191 (2016).

${ }^{191}$ See 33 U.S.C. $§ 1321(b)(3)-(4)$.

19240 C.F.R. $\$ 110.6$ (2019).

193 U.S. Envtl. Protection Agency, National Response Center, https://www.epa.gov/emergency-response/national-response-center (last updated Jun. 21, 2017).

194 U.S. Coast Guard, supra note 180.

195 Samira Daneshgar Asl et al., supra note 190, at 188.

196 Phone conversation with Madeline Voitier, Policy and Legal Specialist, Oceana \& Employee of EPA Oil information Center (Mar. 22, 2019 \& Apr. 9, 2019) (This informational line at 1-800-424-9346 is staffed by Booz Allen Hamilton. The specialist indicated that there is no EPA guidance or frequently asked questions regarding oil spill estimate updated reporting. He pointed to 40 C.F.R. $\S$ 110.6 and highlighted that there is no updating requirement under the notice provision after the initial spill has been reported to the National Response Center or Coast Guard).

19733 U.S.C. § 1321(b)(7)(A) -(D) (penalties were adjusted in 2019, see endnote 198).

198 Civil Monetary Penalty Inflation Adjustment Rule, 84 Fed. Reg. 2,056, 2,059 (Feb. 6, 2019),

https://www.govinfo.gov/content/pkg/FR-2019-02-06/pdf/2019-00785.pdf

199 Phone conversation with Madeline Voitier, supra note 196. 


\section{OCEANA}

200 See 33 U.S.C. $\S 1321(b)(5)$.

201 Samira Daneshgar Asl et al., supra note 190, at 191.

202 Nat'I Comm'n on the BP Deepwater Horizon Oil Spill and Offshore Drilling, supra note 1, at ix.

${ }^{203}$ See Stephen Leahy, Exxon Valdez changed the oil industry forever-but new threats emerge, National Geographic, Mar. 22, 2019,

https://www.nationalgeographic.com/environment/2019/03/oil-spills-30-years-after-exxon-valdez/.

${ }^{204}$ See NOAA Office of Response and Restoration, Spill Containment Methods, https://response.restoration.noaa.gov/oil-andchemical-spills/oil-spills/spill-containment-methods.html (last updated Apr. 9, 2019).

205 NOAA Nat'I Ocean Service, The Exxon Valdez, 25 Years Later, https://oceanservice.noaa.gov/podcast/mar14/mw122exxonvaldez.html (last visited Apr. 10, 2019).

206 The Federal Interagency Solutions Group, Oil Budget Calculator Science and Engineering Team, OIL BUDGET CALCULATOR DEEPWATER HORIZON 40 (2010), https://www.restorethegulf.gov/sites/default/files/documents/pdf/OilBudgetCalc Full HQ-

Print 111110.pdf (According to the Federal Interagency Solutions Group the amount of oil remaining after human intervention and natural dispersal processes was up to $30 \%$ of the total volume of spilled oil. The total spilled volume is about $200,000,000$ gallons, $30 \%$ of which is $60,000,000$ gallons. The Exxon Valdez spill was $11,000,000$ gallons. This volume does not include naturally or chemically dispersed oil.).

207 See Monica Wilson et al., Deepwater Horizon: Where Did the Oil Go?, Sea Grant 2 http://masgc.org/oilscience/oil-spill-sciencewhere-did-oil-go.pdf (last visited Apr. 10, 2019).

${ }^{208}$ Andrew Nikiforuk, Why We Pretend to Clean Up Oil Spills, Hakai Magazine, Smithsonian.com, Jul. 12, 2016, https://www.smithsonianmag.com/science-nature/oil-spill-cleanup-illusion-180959783/.

${ }^{209}$ Scott Waldman, The U.S. Is Not Ready to Clean Up an Arctic Oil Spill, ClimateWire, E\&E News, Jul. 19, 2017, https://www.scientificamerican.com/article/the-u-s-is-not-ready-to-clean-up-an-arctic-oil-spill/. 210 Id.

${ }^{211}$ See 33 U.S.C. $\S 2702$.

212 Id. § 2702(b).

213 Id. § 2704(a).

214 Id. § 2704(a)(3).

215 Id. $\S 2704$ (c)(1)(A)-(B).

216 In re Oil Spill by the Oil Rig "Deepwater Horizon" in the Gulf of Mexico, 77 F. Supp. 3d 500, 503 (E.D. La. 2015).

217 Ron Bousso, BP Deepwater Horizon costs balloon to $\$ 65$ billon, Reuters, Jan. 16, 2018, https://www.reuters.com/article/us-bpdeepwaterhorizon/bp-deepwater-horizon-costs-balloon-to-65-billion-idUSKBN1F50NL.

21826 U.S.C. $\$ 9509$.

219 Nilde Maggie Dannreuther, Federal Emergency Response Framework for Oil Spills: Stafford Act and Oil Pollution Act, Sea Grant (Mar. 7, 2019), http://gulfresearchinitiative.org/new-sea-grant-fact-sheet-on-federal-laws-and-policies-that-govern-oil-spill-response/.

220 Protecting Employees Who Protect Our Environment, Oil Tax for Federal Spill Fund Lapsed with New Year (Jan. 14, 2019), https://www.peer.org/news/press-releases/oil-tax-for-federal-spill-fund-lapsed-with-new-year.html (current trust fund balance listed under "look at current balance in the Oil Spill Liability Trust Fund" link).

221 U.S. Coast Guard, The Oil Liability Trust Fund (OSLTF), https://www.uscg.mil/Mariners/National-Pollution-FundsCenter/About NPFC/OSLTF/ (last visited Apr. 10, 2019).

22226 U.S.C. $\S 4611(f)(2)$.

${ }^{223}$ Congress.gov, S.617 - Tax Extender and Disaster Relief Act of 2019, https://www.congress.gov/bill/116th-congress/senatebill/617/text (last visited Apr. 10, 2019).

224 26 U.S.C. $\$ 9509$ (c)(2)(A).

225 Jonathan L. Ramseur, Oil Spills in U.S. Coastal Waters: Background, Governance, and Issues for Congress, CONGRESSIONAL RESEARCH SERVICE 21 (Apr. 30, 2010), https://www.epw.senate.gov/public/ cache/files/d/b/db4335ea-2eac-4e97-b37d-

7bb90bb4b165/01AFD79733D77F24A71FEF9DAFCCB056.crs-oilspills043010.pdf.

226 Jonathan L. Ramseur, Deepwater Horizon Oil Spill: Recent Activities and Ongoing Developments, CONGRESSIONAL RESEARCH SERVICE 6 (Apr. 17, 2015), https://fas.org/sgp/crs/misc/R42942.pdf.

${ }_{227}$ Melissa Whaling, Too Much To Lose: Offshore Drilling \& Hurricanes in the Southeast, SOUTHERN ENVIRONMENTAL LAW CENTER 1 (Oct. 2018), https://www.southernenvironment.org/uploads/publications/SELC Hurricane Report F.pdf.

228 U.S. Gov't Accountability Off., Testimony Before the Subcommittee on Energy and Mineral Resources Committee on Natural Resources, House of Representatives - Offshore Oil and Gas Resources Information on Infrastructure Decommissioning and Federal Financial Risk Statement of Frank Rusco, Director of Natural Resources and Environment 11 (May 17, 2017),

https://www.gao.gov/assets/690/684646.pdf.

${ }^{229}$ See Bureau of Ocean Energy and Mgmt., 2016 Update of Occurrence Rates for Offshore Oil Spills 23 (Jul. 13, 2016), https://www.bsee.gov/sites/bsee.gov/files/osrr-oil-spill-response-research//1086aa.pdf. 


\section{OCEANA}

${ }^{230}$ Peg Howell, BP oil spill still haunts off-shore drilling industry 8 years later, CNBC (Apr. 20 2018, 1:11 PM),

https://www.cnbc.com/2018/04/20/off-shore-drilling-is-still-a-terrible-idea-8-years-after-bp-oil-spill.html.

${ }^{231}$ Whaling, supra note 227 , at 3.

232 U.S. Gov't Accountability Off., Climate Change: Energy Infrastructure Risks and Adaptation Efforts 12 (Jan. 31, 2014),

https://www.gao.gov/assets/670/660558.pdf.

233 James Bradbury et al., Climate Change and Energy Infrastructure Exposure to Storm Surge and Sea-Level Rise, U.S. DeP'T OF ENERGY 13

(Jul. 2015); https://www.energy.gov/sites/prod/files/2015/07/f24/QER\%20Analysis\%20-

\%20Climate\%20Change\%20and\%20Energy\%2OInfrastructure\%20Exposure\%20to\%20Storm\%20Surge\%20and\%20Sea-

Level\%20Rise 0.pdf.

${ }^{234}$ Entergy, Building a Resilient Energy Gulf Coast: Executive Report 1 (2010)

http://www.entergy.com/content/our community/environment/GulfCoastAdaptation/Building a Resilient Gulf Coast.pdf.

${ }^{235}$ Whaling, supra note 227 , at 1.

${ }^{236}$ Bureau of Safety and Envtl. Enforcement, Annual Report 6 (2016),

https://www.bsee.gov/sites/bsee.gov/files/bsee 2016 annual report v6b.pdf.

${ }^{237} \mathrm{See}$ Nat'l OCEANIC ANd Atmospheric Ass'N's Damage Assessment, Remediation, and Restoration Program: Taylor Energy, https://darrp.noaa.gov/oil-spills/taylor-energy (last visited Apr. 9, 2019).

${ }^{238}$ Defendant's Response to Mot. for Summary Judgment, 2, Taylor Energy Co. LLC v. United States, No. 16-12C, (U.S. Ct. of Fed. Cl.), https://www.courtlistener.com/recap/gov.uscourts.uscfc.32172/gov.uscourts.uscfc.32172.81.0.pdf.

${ }^{239}$ BuREAU OF SAFETY AND ENVTL. ENFORCEMENT'S INCIDENT ARCHIVE: TAYLOR ENERGY OIL DISCHARGE AT MC-20 SITE AND ONGOING RESPONSE EFFORTS (last visited Apr. 9, 201), https://www.bsee.gov/newsroom/library/incident-archive/taylor-energy-mississippicanyon/ongoing-response-efforts.

${ }^{240}$ Defendant's Response to Mot. for Summary Judgment, supra note 238 (The 10,000 to 30,000 gallons spill estimate was calculated by multiplying the number of gallons in a barrel by the number of estimated barrels spilled. There are 42 gallons in a barrel. The estimated 250 to 700 barrels of oil being spilled per day multiplied by 42 gallons equals 10,500 to 29,400 gallons of oil spilled per day).

${ }^{241}$ BUREAU OF SAFETY AND ENVTL. ENFORCEMENT'S INCIDENT ARCHIVE, supra note 239.

${ }^{242}$ See Nat'l OCEanic and Atmospheric Ass'N's Damage Assessment, Remediation, and Restoration Program: Taylor Energy, https://darrp.noaa.gov/oil-spills/taylor-energy (last visited Apr. 9, 2019).

243 ld.

${ }^{244}$ Whaling, supra note 227 , at 5 .

245 Gaye S. Farris, The Major Hurricanes of 2005: a Few Facts, U.S. GEOGRAPHIC SURVEY 14 (2007)

https://pubs.usgs.gov/circ/1306/pdf/c1306 ch2 b.pdf.

246 U.S. Gov't Accountability Office, Climate Change: Energy Infrastructure Risks and Adaptation Efforts 12-13 (2014), https://www.gao.gov/assets/670/660558.pdf.

${ }^{247}$ Craig Zamuda et al. Chapter 4: Energy. Impacts, Risks, and Adaptation in the United States, THE U.S GLOBAL CHANGE ReSEARCH

Program's Fourth National Climate Assessment, Volume II 178 (2018),

https://nca2018.globalchange.gov/downloads/NCA4 Ch04 Energy Full.pdf.

248 Lars Herbst, Safety in the New Offshore World, BUREAU OF SAFETY AND ENVTL. ENFORCEMENT 5 (May 4, 2017),

https://www.bsee.gov/sites/bsee.gov/files/lars-herbst-otc-presentation.pdf.

249 U.S. Dep't of Interior, Budget Justifications and Performance Information Fiscal Year 2019, BUREAU OF SAFETY AND ENVTL.

ENFORCEMENT 11-12 (2019), https://www.bsee.gov/sites/bsee.gov/files/budget-justifications//fy2020-bsee-justification.pdf.

25030 C.F.R. $\$ 250.1703(2019)$.

${ }^{251}$ Bureau of Safety and Envtl Enforcement, Idle Iron Decommissioning Guidance for Wells and Platforms - NTL No. 2018-G03 1 (Dec.

11, 2018), https://www.bsee.gov/sites/bsee.gov/files/notices-to-lessees-nt///ntl-2018-g03.pdf.

252 Bureau of Safety and Envtl Enforcement, Idle Iron, https://www.bsee.gov/what-we-do/environmental-

focuses/decommissioning/idle-iron (last visited Apr. 10, 2019).

25330 C.F.R. $\$ 250.1703$ (2019).

25430 C.F.R. $\$ 556.900$ (2019).

255 U.S. Gov't Accountability Off., OFFSHORE OIL AND GAS RESOURCES Actions Needed to Better Protect Against Billions of Dollars in Federal Exposure to Decommissioning Liabilities 2 (Dec. 2015), https://www.gao.gov/assets/680/674353.pdf.

256 Id. at 23.

${ }^{257}$ Id. at 25-26.

258 Id. at 24. 


\section{OCEANA}

${ }^{259}$ Notice of Availability of Notice to Lessees and Operators of Federal Oil and Gas, and Sulfur Leases, and Holders of Pipeline Right-of-Way and Right-of-Use and Easement Grants in the Outer-Continental Shelf-Requiring Additional Security, 81 Fed. Reg. 46,599 (Jul. 18, 2016), https://www.govinfo.gov/content/pkg/FR-2016-07-18/pdf/2016-16846.pdf.

${ }^{260}$ Exec. Order No. 13,795, 82 Fed. Reg. 20,815 (May 3, 2017), https://www.govinfo.gov/content/pkg/FR-2017-05-03/pdf/201709087.pdf.

${ }^{261}$ BOEM, BOEM Withdraw Sole Liability Orders (Feb. 17, 2017), https://www.boem.gov/note02172017/.

262 Tom Mitro, Fewer Protection For Abandoned Offshore Oil Production Platforms Will Be Risky, FORBES (Mar. 28, 2018), https://www.forbes.com/sites/uhenergy/2018/03/28/fewer-protections-for-abandoned-offshore-oil-production-platforms-willbe-risky/\#4d82bda9827f.

${ }^{263}$ Exec. Order No. 13,783, 82 Fed. Reg. 16,093 (Mar. 28, 2017), https://www.govinfo.gov/content/pkg/FR-2017-03-31/pdf/201706576.pdf.

264 Id.

265 Exec. Order No. 13,795, 82 Fed. Reg. 20,815, 20,816-20,817 (May 3, 2017), https://www.govinfo.gov/content/pkg/FR-201705-03/pdf/2017-09087.pdf.

${ }^{266}$ See Blowout Preventer Systems and Well Control Revisions, 83 Fed. Reg. at 22,128.

${ }^{267}$ Bureau of Safety and Envtl. Enforcement, Production Safety Systems Rule (Nov. 2016), https://www.bsee.gov/guidance-andregulations/regulations/production-safety-systems-rule.

268 Oil and Gas Production Safety Systems, 81 Fed. Reg. at 61859.

269 Id. at 61,875.

${ }^{270}$ Bureau of Safety and Envtl. Enforcement, Production Safety Systems Rule (Nov. 2016), https://www.bsee.gov/guidance-andregulations/regulations/production-safety-systems-rule.

${ }^{271}$ Blowout Preventer Systems and Well Control, 81 Fed. Reg. at 25,888.

272 See Bureau of Safety and Envtl. Enforcement, Well Control Final Rule Fact Sheet, https://www.doi.gov/sites/doi.gov/files/uploads/FACT\%20SHEET-\%20Well\%20Control\%20Final\%20Rule\%20-\%20FINAL.pdf (last visited Apr. 10, 2019).

273 See Blowout Preventer Systems and Well Control, 81 Fed. Reg. at 25893.

27430 C.F.R. $\S 250.732$ (2019).

275 Blowout Preventer Systems and Well Control Revisions, 83 Fed. Reg. at 22,130.

27630 C.F.R. $\S 250.414$ (2019).

277 Blowout Preventer Systems and Well Control Revisions, 83 Fed. Reg. at 22,133.

278 See id.

${ }^{279}$ Nat'I Comm'n on the BP Deepwater Horizon Oil Spill and Offshore Drilling, supra note 1, at 252.

28030 C.F.R. $\S 250.724$ (2019).

${ }^{281}$ See Blowout Preventer Systems and Well Control Revisions, 83 Fed. Reg. at 22,137.

282 See Blowout Preventer Systems and Well Control, 81 Fed. Reg. at 25,896.

${ }^{283}$ See ld.

284 Id. at 26,032-26,034.

285 Blowout Preventer Systems and Well Control Revisions, 83 Fed. Reg. at 22,141 \& 22,143 ("BSEE is requesting comments on whether the BOP testing interval should be 7 days, 14 days, or 21 days for all types of operations.").

286 Id. at 22,138.

287 See David Hilzenrath, supra note 7.

288 Blowout Preventer Systems and Well Control Revisions, 83 Fed. Reg. at 22, 141-22,142.

28930 C.F.R. $\S 250.737$ (b)(2)-(3) (2019).

290 Bureau of Safety and Envtl. Enforcement, OIL AND GAs Sulfur OPERATIONS ON THE OUtER CONTINENTAL SHELF BLOWOUT PREVENTER AND Well Control ReVISIONS INITIAL Reg. IMPACt ANALYSIS RIN: 1014-AA39, 38 (2018),

https://www.regulations.gov/document?D=BSEE-2018-0002-0003 (BSEE determined cost savings aggregate over the ten-year period to be $\$ 946$ million undiscounted, $\$ 824$ million discounted at $3 \%$, and $\$ 693$ million discounted at $7 \%$ ).

${ }^{291}$ Blowout Preventer Systems and Well Control Revisions, 83 Fed. Reg. at 22, 129.

292 Ron Bousso, supra note 217.

293 Exec. Order No. 13,795, 82 Fed. Reg. at 20,816.

294 Bureau of Ocean Energy Mgmt., BOEM Withdraws Sole Liability Orders Further Review of Complex Financial Assurance Issues Warranted (Feb. 17, 2017), https://www.boem.gov/note02172017/.

295 Introduction to the Unified Agenda of Federal Regulatory and Deregulatory Actions-Fall 2018, 83 Fed. Reg. 57,804, 57,894 \&

57,898 (Nov. 16, 2018), https://www.govinfo.gov/content/pkg/FR-2018-11-16/pdf/2018-24084.pdf. 


\section{OCEANA}

${ }^{296}$ Bureau of Safety and Envtl. Enforcement, Interior Issues Final Regulations to Raise Safety \& Environmental Standards for Any Future Exploratory Drilling in U.S. Arctic Waters (Jul. 7, 2016), https://www.bsee.gov/newsroom/latest-news/statements-and-

releases/press-releases/interior-issues-final-regulations-to.

${ }^{297}$ Requirements for Exploratory Drilling on the Arctic Outer Continental Shelf, 81 Fed. Reg. 46,478, 46,562- 46,563 (Jul. 15,

2016), https://www.govinfo.gov/content/pkg/FR-2016-07-15/pdf/2016-15699.pdf.

298 Bureau of Ocean Energy Mgmt., 2019-2024 National Outer Continental Shelf OIL and Gas Leasing, Draft Proposed Program 1 (2018), https://www.boem.gov/NP-Draft-Proposed-Program-2019-2024/.

${ }^{299}$ See ld. 